\title{
Petrogenesis and Metallogenesis of Malek Siah Kuh Adakite-Like Rocks and Associated Hydrothermal Mineralization (Sistan Area, Iran)
}

\author{
Mohsen Javan Khosh Kholgh1, Morteza Razmara ${ }^{2 *}$, Mohammad Ali Arian1 \\ ${ }^{1}$ Department of Geology, Faculty of Science, North Tehran Branch, Islamic Azad University, Tehran, Iran \\ ${ }^{2}$ Department of Geology, Ferdowsi University of Mashhad, Mashhad, Iran \\ Email : ${ }^{*}$ razmaramorteza@gmail.com
}

How to cite this paper: Kholgh, M.J.K., Razmara, M. and Arian, M.A. (2017) Petrogenesis and Metallogenesis of Malek Siah Kuh Adakite-Like Rocks and Associated Hydrothermal Mineralization (Sistan Area, Iran). Open Journal of Geology, 7, 16701689.

https://doi.org/10.4236/ojg.2017.711112

Received: May 1, 2017

Accepted: May 18, 2017

Published: November 27, 2017

Copyright (c) 2017 by authors and Scientific Research Publishing Inc. This work is licensed under the Creative Commons Attribution International License (CC BY 4.0).

http://creativecommons.org/licenses/by/4.0/

\section{(c) (i) Open Access}

\begin{abstract}
The granitoids-diroretic complex and associated volcanic suits of Malek Siah Kuh (eastern Iran) were examined by RS, XRD, XRF, AAS and ICP-MS methods. The Multispectral data were used for differentiating of lithological units, main alterations, structural trends, and hydrothermally altered minerals. Based on the results of remote sensing, field studies and petrographic data, the complex classified into three main groups: 1) mafic unit (gabbro-basalt), 2) intermediate rocks (diorite-andesite suite) and 3) felsic unit (granitoide rocks). The complex is characterized by high $\mathrm{Al}_{2} \mathrm{O}_{3}$ and $\mathrm{Sr}$ contents as well as high $\mathrm{Sr} / \mathrm{Y}$ and $\mathrm{La} / \mathrm{Yb}$ ratios, while low in $\mathrm{Y}$ and $\mathrm{Yb}$ contents. The geochemical characteristics of these rocks indicate that they are similar to adakite like rocks. The complex is high calc-alkaline to shoshonitic nature. The results indicated derivation from similar silicate melt source followed by differentiation and assimilation of crustal rocks. Based on set of petrological and geochemical relations, 3 distinct stages of mineralization process can be recognized. 1) It is differentiation during magma evolution as well as metal enrichment and subsolidus leaching by hot fluids. 2) It occurred by ascending of the gas-rich magma and release of $S$ and As. 3) It was accompanied by hydrothermal activities leading to the generation of sulfidation and associated polymetallic $(\mathrm{Cu}, \mathrm{Au}, \mathrm{Fe})$ mineralization.
\end{abstract}

\section{Keywords}

Malek Siah Kuh Igneous Complex, Differentiation, Assimilation 


\section{Introduction}

Granitoid rocks are characterized by a large compositional diversity arising from different source compositions, variable melting conditions, chemical complexity, magma mixing, fractional crystallization and crustal contamination [1] [2] [3].

Based on set of series of published sources [4]-[14], rocks referred to as adakites show following characteristics: $\mathrm{SiO}_{2} \geq 56 \mathrm{wt} \%$, high $\mathrm{Na}_{2} \mathrm{O}$ contents (3.5 wt. $\% \leq \mathrm{Na}_{2} \mathrm{O} \leq 7.5$ wt.\%), correlated low $\mathrm{K}_{2} \mathrm{O} / \mathrm{Na}_{2} \mathrm{O}(\sim 0.42), \mathrm{Al}_{2} \mathrm{O}_{3} \geq 15$ wt\%, $\mathrm{MgO}<3 \mathrm{wt} \%, \mathrm{Sr} \geq 400 \mathrm{ppm}, \mathrm{Y} \leq 18 \mathrm{ppm}, \mathrm{Yb} \leq 1.9 \mathrm{ppm}, \mathrm{Ni} \geq 20 \mathrm{ppm}, \mathrm{Cr} \geq 30$ $\mathrm{ppm}, \mathrm{Sr} / \mathrm{Y} \geq 20, \mathrm{La} / \mathrm{Yb} \geq 20$, and ${ }^{87} \mathrm{Sr} /{ }^{86} \mathrm{Sr} \leq 0.7045$. Their $\mathrm{Fe}_{2} \mathrm{O}_{3}+\mathrm{MgO}+\mathrm{MnO}$ $+\mathrm{TiO}_{2}$ contents are moderately high ( $\left.\sim \mathrm{wt} . \%\right)$, with high $\mathrm{Mg \#} \mathrm{(} \mathrm{0.51)}$ and high $\mathrm{Ni}$ and $\mathrm{Cr}$ contents (24 and $36 \mathrm{ppm}$, respectively) [4] [15] also reported typically high $\mathrm{Sr}$ contents (>400 ppm) with extreme concentrations reaching $3000 \mathrm{ppm}$. Rare earth element (REE) patterns are strongly fractionated $(\mathrm{La} / \mathrm{Yb})>10)$ with typically low heavy REE (HREE) contents ( $\mathrm{Yb} \leq 1.8 \mathrm{ppm}, \mathrm{Y} \leq 18 \mathrm{ppm})$ [15]. High- $\mathrm{SiO}_{2}$ adakites (HSA) have lower $\mathrm{MgO}$ (0.5 to 4 wt.\%), $\mathrm{CaO}+\mathrm{Na}_{2} \mathrm{O}(\sim 11$ wt.\%) and $\mathrm{Sr}(\sim 1100 \mathrm{ppm})$, compared to LSA ( $\mathrm{MgO}=4-9$ wt.\%; $\mathrm{CaO}+\mathrm{Na}_{2} \mathrm{O}>$ $10 \mathrm{wt} . \% ; \mathrm{Sr}>1000 \mathrm{ppm}$ [15]. HSA are the direct result of melting subducted hydrated basalt and variably contaminating those slab-melts by peridotite assimilation as they ascend through the mantle wedge [15]. Adakite-like rocks can be related to some deep dynamic processes, such as oceanic crust subducting [7], basalt underplating [16] and delamination of lower crust [17]. The shoshonitic magmas, in contrast, originated mainly from an enriched mantle metasomatized by subducted oceanic sediments [18].

The study area shows geological and structural complexity due to its location between major structural zones of the Lut block, Afghan block, central Iranian blocks and several magmatic episodes. As a result an important mineralization is originated from this complexity. Their complex lithological units and strong re-mobilization cause ambiguity on the primary setting of the ore deposition. The aim of this study was to investigate the mechanism of magma differentiation processes, parental magma compositions, changes and processes involved in the formation of the complex and related ore deposits.

\section{Geological Setting}

The study area is located between $60^{\circ} 50^{\prime}-60^{\circ} 57^{\prime}$ East longitudes and $29^{\circ} 53^{\prime}$ $29^{\circ} 55^{\prime}$ North latitudes (40 km north of Zahedan) in Sistan and Baluchestan Province (Iran). The Sistan region is located in southeastern Iran close to the Iranian borders with Pakistan and Afghanistan. Late Cretaceous to Tertiary rocks of the Sistan suture zone separate two blocks of continental character (Figure 1): the Lut block to the west and the Afghan block to the east [19]. The Sistan suture zone (SSZ) represent a north-south trending segment of an ocean (the Sistan Ocean) in Early Cretaceous [20]. Since Early Cretaceous the Sistan suture zone (SSZ) has undergone a complex history marked by rifting, subduction, ophiolite emplacement, continent-trench collision, uplift, at least three 

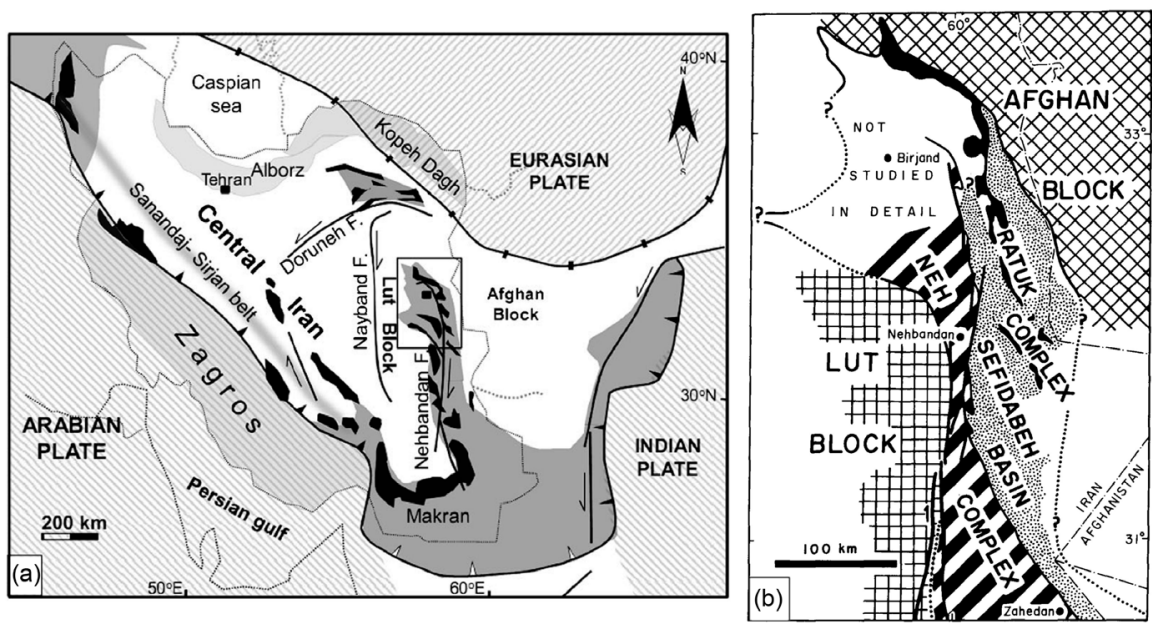

Figure 1. (a) Location of the Sistan suture zone, the Lut and Afghan blocks, and surrounding physiographic and geologic features [21]; (b) Major geologic subdivisions of the Sistan suture zone [20].

phases of Cenozoic deformation and several magmatic episodes have been recorded throughout its dynamic history [21].

The study area is mainly comprised of the plutonic and volcanic rocks (from Cretaceous to Eocene volcanic group). The granitoid plutons are elongated in a NW-SE direction and have been called the Zahedan-Saravan granitoids [21].

According to the nature of the components and degree of mixing, the Sistan Suture Zone rocks have been grouped into 3 basic lithotectonic units: 1) ophiolites in various degrees of disarray (with Senonian to Maastrichtian ages); 2) phyllite and phyllonite of late Cretaceous to Eocene age; and 3) terrigenous marine sedimentary rocks [20]. The phyllite and phyllonite are weakly metamorphosed turbidite successions constituting almost half of the Sistan Suture Zone [20].

$\mathrm{K}$-Ar dating of biotite samples from different areas in the intrusive belt indicates solidification ages in the range of $31-33 \mathrm{Ma}$ for the main phase intrusions [21]. From the middle Cretaceous to recent (Figure 2), the area of the Sistan suture zone has undergone a number of important tectonic events and continued convergence between the Lut and Afghan blocks resulted in widespread folding and conjugate strike-slip faulting [20]. Several mineral deposit occurrences with variable $\mathrm{Au}$ and $\mathrm{Cu}$ anomalous are hosted in the vicinity of granitoid, mafic and ultramafic rocks and iron oxide veins.

\section{Analytical Methods}

Remote sensing techniques have been used for identification of lithological rock units and altered zones and were confirmed on the field before sampling. Multispectral and hyperspectral remote sensing has been used extensively around the globe for lithological and mineral mapping [22] [23] [24] [25]. With the advent of multispectral sensors, lithological discrimination and mineral potential mapping were possible from space/airborne platforms [26] [27]. Hyperspectral 


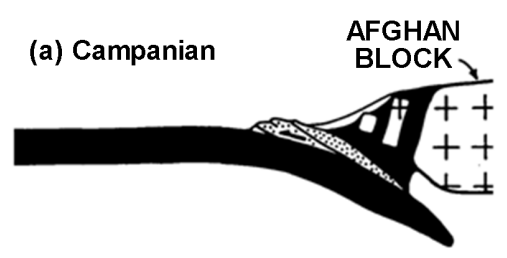

(b) Maastrichtian
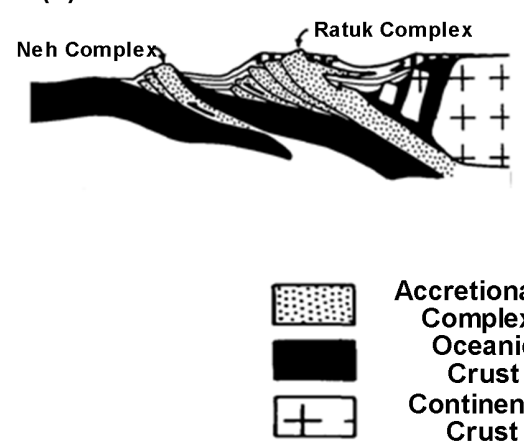

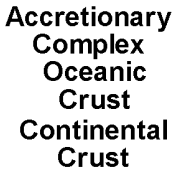

(c) Paleocene

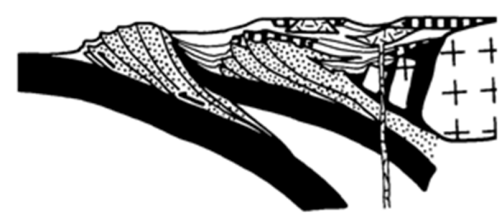

(d) Oligocene

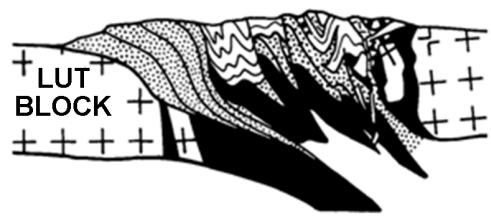

Limestone

Sedimentary Rock (undiff.)

Igenous Rock

Figure 2. The tectonic evolution of the Sistan suture zone [20].

sensors provide a unique combination of both spatially and spectrally contiguous images that allow precise identification of minerals [28].

A total of 35 samples (from volcanic and plutonic rocks) were collected from outcrops and 15 samples were selected for determination of major and selected trace and rare element analysis. Major element contents were determined by $\mathrm{XRF}$ whereas trace and rare elements were determined by inductively coupled plasma mass spectrometer (ICP-MS) at Geological Survey of Iran.

Detailed mineralogical studies and modal analysis were performed by X-ray Diffraction (XRD) but textural analyses were carried out by Petrographic microscope and scanning electron microscope (SEM) equipped with an EDS system, in the electron microscopy laboratory of Ferdowsi university of Mashhad. X-ray diffraction (XRD) analysis of the crystallographic phases was performed on over 15 samples. Quantitative XRD analysis was accomplished in order to accurately determine the mineralogical composition of fine-grain volcanic rocks and altered products. All samples were crushed to a fine powder and placed on single silicon crystal sample holder. XRD patterns were collected from the powdered samples using a $\mathrm{CuK} \alpha$ source. All samples were analyzed from $5^{\circ}$ to $75^{\circ} 2 \theta$. Operating conditions were $40 \mathrm{kV}$ X-ray beam and $35 \mathrm{~mA}$ X-ray beam current. Mineral phases present were identified by computer-aided searches using Modern SaxAcq acquisition software.

\section{Results and Discussion}

\subsection{Remote Sensing}

The remote sensing data plus field and petrological studies have provided possible separation of lithological units with high accuracy in the study area. The Multispectral data was used for differentiating of lithological units (Figure 3), 


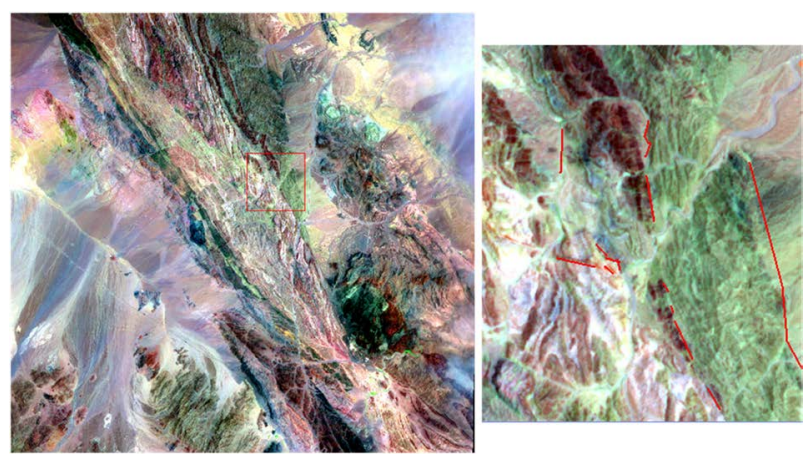

Figure 3. Color view of Malek Siah Kuh area and its surrounding area.

main alterations (Figure 4), structural trends, hydrothermally altered minerals (Figure 5), surface mineral identification and mapping (Figure 6). The main litholigcal units and structural trends were identified as a linear body trending NW-SE direction parallel to the major shear zone of the area. The results of remote sensing (RS) and petrographic data provided a means for classification of lithological units into 3 units. The granitoid stock consists of monzogranite, granodiorite unites in the south but quartz-diorites and quartz-monzogranites in the north of the area. Analysis of remote sensing data and field studies suggested that mafic to intermediate and acidic intrusive-extrusive sequence is present in the study area (Figure 6). Moreover, hyperspectral data was used to distinct the location of hydrothermally alterated minerals in Malek Siah Kuh area. Hematite and arsenopyrite with minor quantity of limonite and goethite are found in the study area.

\subsection{Petrography}

The igneous complex at Malek Siah Kuh area is comprised of a wide range of mafic and intermediate to acidic intrusive-extrusive sequences. The complex can be subdivided into three groups: 1) mafic unit (gabbro-basalt), 2) Intermediate rocks (diorite-andesite suite and much less trachyandesites) and 3) felsic unit (granitoide rocks). The predominant units in plutonic rocks are chains of diorite and granodiorite suits. The diorite rocks in the Malek Siah Kuh batholith are exposed in the north-eastern part of the study area. These rocks are medium to coarse grained, characterized by granular, ophitic to subophitic textures. Although all types of diorites in the study area are mineralogically similar but the dioritic unites comprise varying lithologies of altered gabrodiorite, meladiorite, mesodiorite and leucodiorite. The principal constituent minerals in these rocks are plagioclase (andesine) (44\% to $56 \%$ ), orthoclase ( $8 \%$ to $16 \%$ ) and $\beta$-quartz ( $5 \%$ to $15 \%$ ), but augite ( $5 \%$ to $15 \%$ ), hornblende ( $15 \%$ to $20 \%$ ), epidote, calcite, zoisite and clinozoisite, occur as minor constituents. The XRD analysis of dioritic altered rocks revealed the assemblage of calcite, zoesite, clinozoesite and epidote. In meladioritic rocks, saussuritization products (calcite, clinozoesite and epidote) occur as altered minerals. The most abundant accessory minerals are 

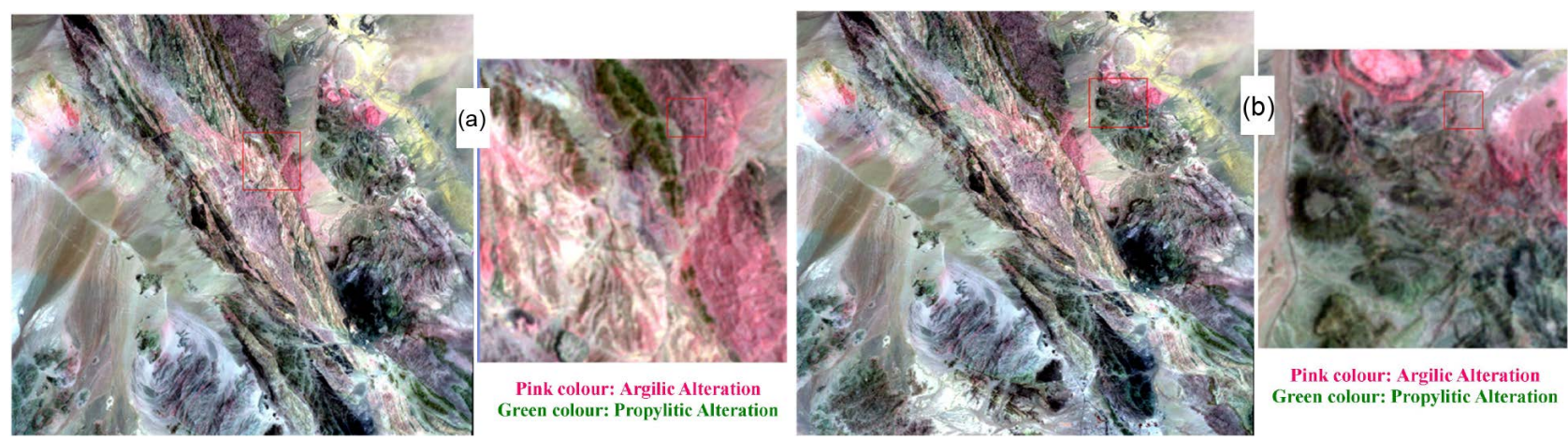

Figure 4. Pink colours show argillic alteration zones, green colours show propylitic alteration zones.
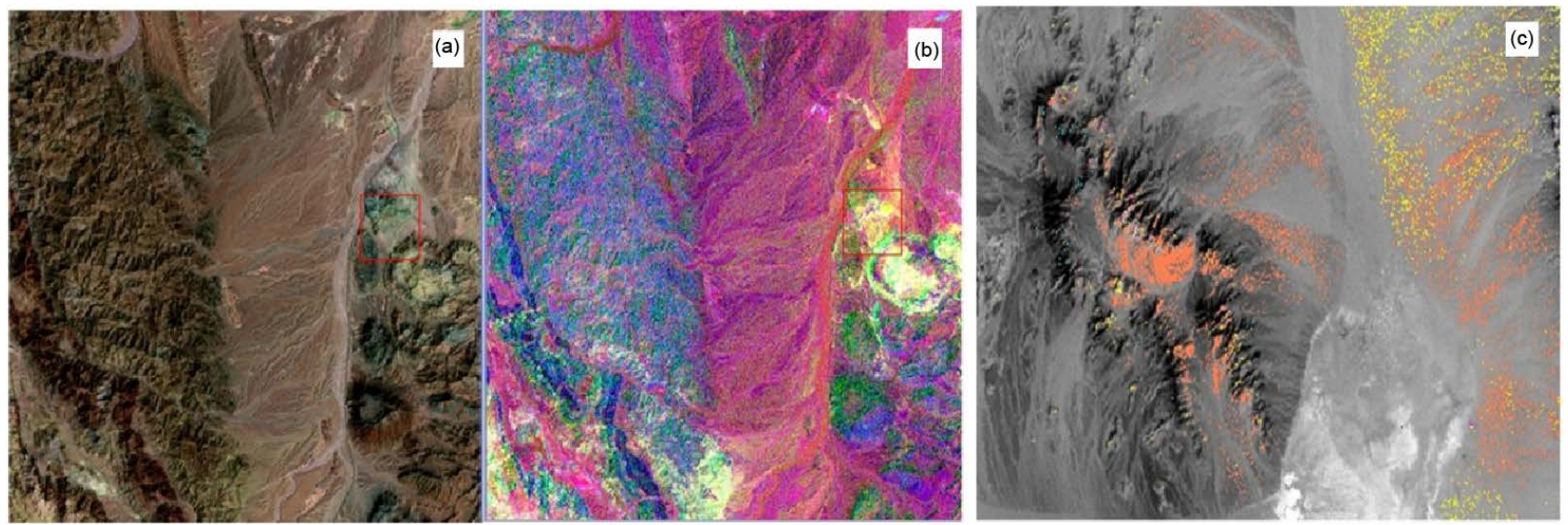

Figure 5. (a) Malek Siah Kuh area and its surrounding area; (b) Yellow colours show hydrothermal alteration zones; (c) Distribution of iron minerals (hematite and goethite) on the Malek Siah Kuh area.

magnetite, titanomagnetite and opaque minerals. Although intermediate rocks occur as stocks (small plutons) and thick dikes but a large pluton is observed in the south part of the study area.

The volcanic rocks consist mainly of andesite, trachyandesite and basalt (Figure 7). They are dark-colored to brown with phenocrysts of plagioclase (labradorite to andesine), mafic minerals (hornblende, Pyroxene) and alkali feldspar with porphyritc and gleumeroporphyritc textures. The more Ca-rich members of the plagioclase series (phenocrysts) are completly zoned with inner zones altered to fine cryptocrystalline mixture (sausuritization). The process of sausuritization had been produced calcite, zoesite, prehnite, clinozoesite and epidote. In volcanic rocks (andesites and trachyandesites), the fine groundmass consists of plagioclase (andesine), hornblende, pyroxene (augite) and alkali feldspar. Moreover, titanomagnetite and opaque minerals are present as accessory minerals (Figure 8).

Granitoid unit is the most abundant plutonic rock in the area and consists mainly of granodiorite but includes other rocks such as monzogranite and quartz monzonite. Granodiorite rocks are often found related with typical hydrothermal minerals and they vary from medium to coarse grained. In this group, the dominant mineral assemblage is plagioclase (oligoclase) (40\% to 

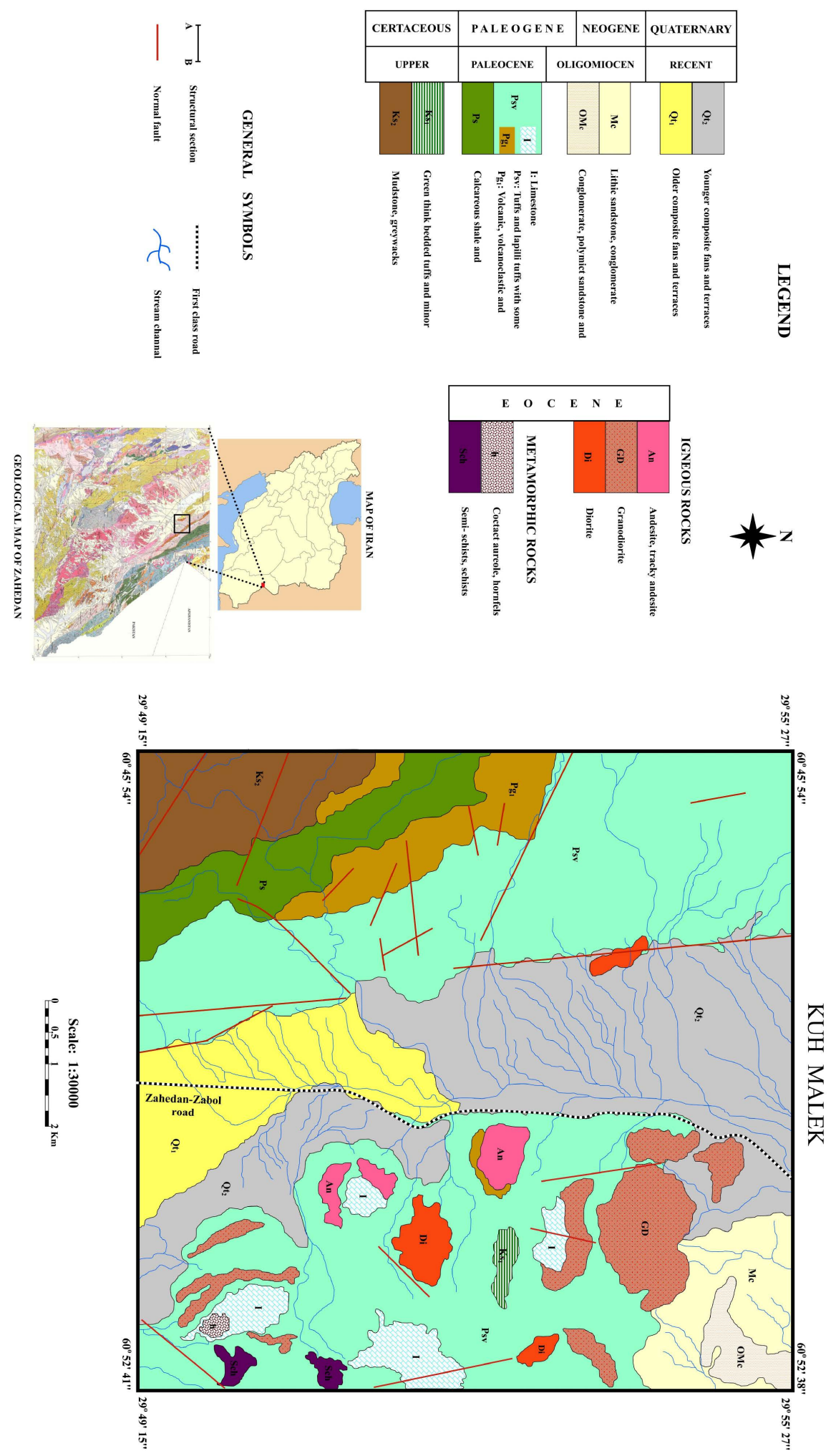

Figure 6. Simplified geologic map of the study area showing the spatial distribution of igneous complex in the Malek Siah Kuh area.

$50 \%$ ), K-feldspar (orthoclase) (15\% to $20 \%$ ), $\beta$-quartz ( $25 \%$ to $30 \%$ ) with minor phases (biotite, sphene) (10\%) plus chlorite as a product of alteration of biotite 

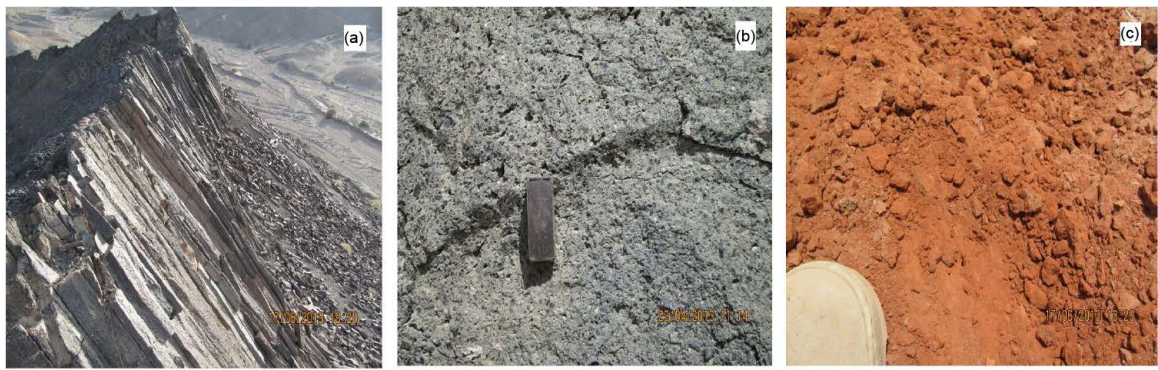

Figure 7. (a) Field photograph of columnar basalt; (b) magnetite-bearing basaltic andesite; (c) altered products (hematite) of iron bearing volcanic rocks.
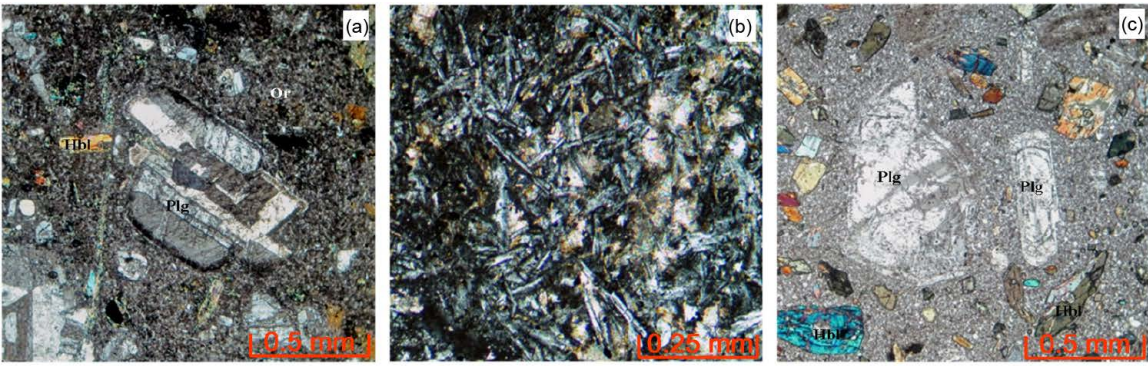

Figure 8. (a) Thin-section photograph (in cross-polarized light; XPL) of a xenocrystic granodiorite, showing a plagioclase xenocryst; (b) Thin-section photograph (in XPL) of diorite, showing a small blade plagioclase; (c) Thin-section photograph (in XPL) of porphyritic andesite, showing a hornblende and plagioclase xenocryst with feldspar matrix.

and hornblende. Porphyritic andesites and trachyandesites (as the main volcanic unit in the study area) occur in the central and eastern part of the area.

\subsection{Geochemestry}

Geochemical data from the igneous complex have been used to characterize the petrogenesis and tectonic setting of the plutonic and associated volcanic rocks of the study area. Major oxides, trace and rare earth element (REE) abundances of 15 samples from the complex were analyzed by XRF, ICP-MS and AAS (Table 1). The result data indicate that unaltered trachyandesite is silica oversaturated with $\mathrm{SiO}_{2}$ ranging from $55.46 \%$ to $60.45 \%$ and alkali contents $\left(\mathrm{K}_{2} \mathrm{O}+\mathrm{N}_{2} \mathrm{O}\right)$ ranging from $6 \%$ to $10 \%$ but the intermediate rocks of the area exhibit a narrow range of $\mathrm{SiO}_{2}$ content ( $55 \%$ to $60 \mathrm{wt} . \%$ ).

Moreover, the amount of $\mathrm{SiO}_{2}$ in granodiorites ranging from $63.31 \%$ to $64.1 \%$ and total alkali contents from $5.56 \%$ to $6.46 \%$. As a result, these granodiorites belong to high-K calcalkaline series. The granodiorite is characterized by high LREE contents and low HREE contents. All of the geological and petrological evidences suggest that quartz-diorite, quartz-monzodiorite and granodiorite rocks in Malek Siah Kuh apparently form as a result of fractional crystallization of source magma.

In the TAS diagram [29], the most rocks plot in the fields of sub-alkaline basalt, andesite and trachyandesite (Figure 9). However, variations of silica versus the $\mathrm{FeOt} / \mathrm{MgO}$ and standard AFM diagram (Figure 10) as well as silica versus 
Table 1. Major oxides, trace element and rare earth element (REE) abundances for different rock types of Malek Siah Kuh (north Sistan, Iran).

\begin{tabular}{|c|c|c|c|c|c|c|c|c|c|c|c|c|c|c|c|c|c|c|c|c|c|c|}
\hline Sample & LL8 & LJ6 & LK6 & LM10 & LF14 & $\mathrm{Km} 21$ & $\mathrm{Km} 35$ & $\mathrm{Km} 49$ & LL7 & $\mathrm{Km} 33$ & $\mathrm{Km} 41$ & $\mathrm{Km} 30$ & $\mathrm{Km} 44$ & Km57 & LK10 & Km59 & $\mathrm{Km} 28$ & $\mathrm{Km} 20$ & $\mathrm{Km} 18$ & $\mathrm{Km} 11$ & $\mathrm{Km} 68$ & $\mathrm{Km} 74$ \\
\hline $\mathrm{Si}_{2} \mathrm{O}$ & 50.59 & 1.06 & 51.35 & 52.09 & 53.15 & 55.46 & 55.96 & 56.1 & 56.11 & & 57.28 & 57.63 & & 60.45 & 61.56 & 60.84 & & 61.87 & 63.31 & 63.42 & 63.64 & 64.1 \\
\hline $\mathrm{TiO}_{2}$ & 0.76 & 0.88 & 0.72 & 0.73 & 0.77 & 0.47 & 0.49 & 0.64 & 0.68 & 0.63 & 0.68 & 0.53 & 0.69 & 0.6 & 0.57 & 0.57 & 0.61 & 0.31 & 0.38 & 0.33 & 0.39 & 0.36 \\
\hline $\mathrm{Al}_{2} \mathrm{O}_{3}$ & 13.22 & 12.19 & 11.26 & 13.09 & 12.16 & 17.16 & 14.87 & 18.47 & 11.38 & 14.52 & 18.68 & 12.73 & & & & 14.93 & 16.56 & 16.11 & 16.17 & 15.64 & 17.42 & 15.65 \\
\hline $\mathrm{Fe}_{2} \mathrm{O}_{3}$ & 10 & 8.26 & 8.71 & 8.05 & 8.04 & 4.97 & 7.9 & 5.34 & 7.71 & 7.63 & 5.19 & 6.03 & 5.17 & 6.58 & 5.51 & 5.51 & 4.39 & 5.5 & 5.44 & 5.48 & 5.36 & 4.89 \\
\hline $\mathrm{MnO}$ & 0.18 & 0.14 & & 0.18 & 0.15 & 0.09 & 0.17 & 0.09 & 0.16 & 0.16 & 0.16 & 0.15 & 0.12 & 0.15 & 0.12 & 0.12 & 0.15 & 0.08 & 0.23 & 0.18 & 0.13 & 0.16 \\
\hline $\mathrm{MgO}$ & 8.13 & 10.29 & 9.47 & 6.54 & 7.47 & 2.52 & 5.86 & 3.34 & 6. 48 & 5.96 & 4.31 & 7.21 & 9.25 & 4.73 & 4.19 & 4.19 & 4.76 & 3.12 & 2.23 & 3.27 & 3.16 & 2.74 \\
\hline $\mathrm{CaO}$ & 9.38 & 9. 33 & 9.07 & & 9.88 & 4.21 & 6.8 & 2.87 & 7.82 & 4.87 & 2.74 & 8.31 & 7.04 & 5.18 & 5.97 & 5.97 & 4.62 & 4.85 & 2.5 & 4.84 & 3.14 & 4.31 \\
\hline $\mathrm{Na}_{2} \mathrm{O}$ & 2.99 & 2.08 & 1.98 & 2.16 & 2.58 & 3.46 & 2.36 & & 2.86 & & 3.35 & 2.38 & & & 3.43 & 3.43 & 2.76 & 3.26 & 3.97 & 3.12 & 3.21 & 3.32 \\
\hline $\mathrm{K}_{2} \mathrm{O}$ & 3.02 & 3.73 & 4.81 & 5.07 & 3.92 & 6.82 & 3.01 & 6.65 & 3.46 & 3.46 & 5.86 & 3.17 & 3.37 & 3.67 & 2.16 & 2.16 & 3.11 & 2.63 & 2.49 & 2.44 & 2.71 & 2.63 \\
\hline $\mathrm{P}_{2} \mathrm{O}_{5}$ & 0.41 & 0.59 & 0.78 & 0.69 & 0.41 & 0.62 & 0.23 & 0.68 & 0.51 & 0.58 & 0.54 & 0.37 & 0.42 & 0.49 & 0.3 & 0.3 & 0.39 & 0.038 & 0.23 & 0.14 & 0.1 & 0.13 \\
\hline L.O.I & 1.32 & 1.17 & 1.32 & 1.94 & 1.47 & 3.96 & 2.27 & 2.21 & 2.56 & 2.56 & 1.08 & 1.16 & 0.98 & 1.56 & 0.99 & 1.83 & 2.03 & 1.74 & 2.78 & 1.1 & 0.89 & 1.64 \\
\hline Total & 100 & 99.72 & 99.67 & 99.74 & 100 & 99.74 & 99.92 & 99.93 & 99.73 & 99.89 & 99.87 & 99.67 & 99.86 & 99.74 & 99.73 & 99.85 & 100.6 & 99.85 & 99.73 & 99.96 & 99.97 & 99.93 \\
\hline $\mathrm{V}$ & 94.8 & 100.2 & 101.9 & 99.46 & 99.35 & 137.4 & 127.1 & 139.5 & 96.5 & 129.3 & 89.4 & 96.5 & 94.6 & 96.8 & 99.1 & 99.6 & 110.3 & 142.5 & 129.4 & 136.8 & 120.2 & 110.7 \\
\hline $\mathrm{Cr}$ & 134 & 348 & 517 & 128 & 479 & 180 & 125 & & 122 & 212 & 0 & T & 120 & 10 & 100 & 00 & 117 & 159 & 151 & 150 & 143 & 118 \\
\hline $\mathrm{Ni}$ & 52.6 & 61.5 & 55.7 & 52.9 & 54.3 & 57.3 & 52.4 & 77.6 & 53.7 & 60 & & 77.6 & 69.8 & 59.4 & 51.8 & 59.3 & 78.1 & 90.2 & 98.6 & 101.4 & 71.3 & 91.5 \\
\hline Co & 34.6 & 39.2 & 38.9 & & 37.4 & 11.4 & 12.1 & & 26.3 & & 12.6 & 12.7 & & & 19.3 & & & & & 12.2 & 13.8 & 14.5 \\
\hline $\mathrm{Zn}$ & 76.3 & 55.9 & 149 & 101.2 & 58.9 & 56.4 & 74.4 & 55.2 & 101.7 & 51.4 & 63.3 & & 57.5 & 54.4 & 87.6 & 55.8 & 55.4 & 52.1 & 53.8 & 50.5 & 58.3 & 64.3 \\
\hline $\mathrm{Ga}$ & 16.5 & 14.3 & 14.1 & 15 & 15.9 & & 16.3 & 14.2 & 14.2 & 15.4 & 14.3 & 17.8 & 14.4 & 18.1 & 22.2 & 21.3 & 17.4 & 18.1 & 19 & 19.6 & 18.2 & 17.8 \\
\hline $\mathrm{Sn}$ & 2 & 2.3 & 1.8 & 2.2 & & 3 & 3 & 1.9 & 1.9 & 1.9 & 2.2 & 2 & 1.8 & 1.9 & 2.4 & 1.8 & 1.7 & 2 & 2.9 & 1.8 & 2 & 2.4 \\
\hline $\mathrm{W}$ & 3.3 & 4.8 & 6.1 & & 12.5 & 1.5 & 1.2 & & 3.1 & 1.3 & 1.4 & 1.3 & 1.2 & & 7.9 & 1 & & 1.8 & 1.1 & 1.2 & 1.4 & 0.9 \\
\hline $\mathrm{Ba}$ & 1250 & 1212 & 558 & 1623 & 1222 & 337.4 & 315.7 & 426.6 & 1415 & 348.6 & 346.7 & 354.3 & 341 & 320.5 & 1224 & 304.1 & 342.6 & 525.2 & 362.4 & 336 & 396.8 & 278.3 \\
\hline $\mathrm{Sr}$ & 745 & & 791 & & 631 & 301.9 & 270.5 & 281.2 & 710 & 305.5 & 335 & 273.8 & 301.6 & 337.1 & 1237 & 276.6 & 292.1 & 348.9 & 404.9 & 446.7 & 333.4 & 215.7 \\
\hline $\mathrm{Rb}$ & 79.7 & 131.8 & 125.4 & 118.5 & 96.7 & 74.3 & 76.8 & 99.1 & 75.5 & 82.4 & 117.3 & 125.7 & 99.3 & 128.5 & 78.9 & 115.7 & 148.6 & 132.1 & 128.9 & 152.4 & 135.3 & 158.2 \\
\hline $\mathrm{Nb}$ & 5.7 & 12 & 7.4 & 10.2 & 10.1 & 10.5 & 15.7 & 10.2 & 8.6 & 14.5 & 10.7 & 11.6 & 11.4 & 11.1 & 10.6 & 11.5 & 11.6 & 12.3 & 11.1 & 11.9 & 10.9 & 12.2 \\
\hline $\mathrm{Y}$ & 19.6 & 18.9 & 20.6 & 19.5 & 20.3 & 11.3 & 15.2 & 11.1 & 16.9 & 12.4 & 13.9 & 11.3 & 12.6 & 11.8 & 14.1 & 12.6 & 12.6 & 12.2 & 13.5 & 12.2 & 11.5 & 14.7 \\
\hline $\mathrm{Zr}$ & 87.8 & 41.9 & 55.3 & 66.8 & 24.5 & 70.3 & 89.6 & 85.4 & 73.2 & 70.6 & 88.7 & 81.1 & 88.7 & 105 & 20.9 & 91.4 & 106.1 & 99.5 & 120 & 138.3 & 143.9 & 136.5 \\
\hline Cs & 1.5 & & & & & 3.4 & & 3.1 & 1 & 3.9 & & 1.3 & & & 4.9 & 1.8 & 4.6 & 5.7 & 10.6 & 6.2 & 7.1 & 8.4 \\
\hline $\mathrm{Hf}$ & & & & & & & & & & & & & & & & & & & & 4.6 & 4.3 & 5.2 \\
\hline $\mathrm{Ta}$ & & & & & & 1.3 & & & 0.8 & & & & & & & & 12 & 1.1 & 0.9 & 1.2 & .1 & 0.9 \\
\hline Th & & & & & & & & & & & & & & & & & & & & & & 10.2 \\
\hline $\mathrm{U}$ & & & & 2 & & & & & & & & & & & & & & & & 2.8 & 2.4 & 2.7 \\
\hline $\mathrm{La}$ & 17.1 & & & & & 20.6 & & 16.2 & 20.9 & & & & & & & & & & 19.6 & 26.7 & 25.8 & 34.2 \\
\hline $\mathrm{Ce}$ & 33.5 & & & & & & & & 39.5 & & & & & & & & & & & & 49.6 & 41.9 \\
\hline $\operatorname{Pr}$ & 4.4 & 6 & & & & & & & 5 & & & & & & & & & & & & 6.4 & 6.7 \\
\hline $\mathrm{Nd}$ & 18 & 22.7 & 23.9 & 27.3 & & 18.6 & 21.1 & 22.3 & 20.4 & 19.3 & 21.9 & 23.4 & 17.8 & 25.3 & 19.2 & 21.2 & 34.1 & 31.2 & 27.3 & 16.4 & 25.1 & 24.2 \\
\hline $\mathrm{Sm}$ & & & & & & & & & & & & & & & & & & & & & & 4.7 \\
\hline $\mathrm{Eu}$ & & & & & & & & & & & & & & & & & & & & & & 1.1 \\
\hline $\mathrm{Gd}$ & 3.7 & & & & & & & & & & & & & & & & & & 5.2 & 3.9 & 0.1 & 5.7 \\
\hline $\mathrm{Tb}$ & 0.7 & & & & & & & & & & & & & & & & & & 0.9 & 0.7 & 0.9 & 0.9 \\
\hline Dy & 4 & & & & 4.3 & 2.9 & 3.5 & 3.7 & 3.5 & 3.4 & 4.2 & 4.1 & 4.2 & 3.6 & 2.9 & 4.3 & 4.5 & 4.6 & 4.1 & 3.6 & 50 & 3.7 \\
\hline Ho & 0.9 & 0.8 & & & & 0.6 & 0.6 & 0.5 & 0.7 & 0.8 & 0.8 & 0.9 & 0.7 & 0.9 & 0.6 & 0.9 & 0.8 & 0.9 & 0.9 & 0.7 & 0.9 & 0.9 \\
\hline Er & & 2 & & & & & & & 1.8 & & & & & & & & & & 2.5 & 2.3 & 3.1 & 3.4 \\
\hline $\mathrm{Tm}$ & 0.4 & 0.4 & 0.4 & 0.4 & 0.4 & 0.4 & 0.4 & 0.5 & 0.3 & 0.5 & 0.4 & 0.4 & 0.4 & 0.5 & 0.3 & 0.5 & 0.4 & 0.4 & 0.3 & 0.3 & 0.5 & 0.4 \\
\hline $\mathrm{Yb}$ & 2.5 & 2.2 & 2.3 & 2.3 & 2.5 & 1.5 & 1.9 & 2 & 1.9 & 2.3 & 2.2 & 2.1 & 2.5 & 2.3 & 1.5 & 2.1 & 3.4 & 2.6 & 2.5 & 2.2 & 2.1 & 3.4 \\
\hline $\mathrm{Lu}$ & 0.5 & 0.4 & 0.5 & 0.5 & 0.5 & 0.3 & 0.5 & 0.5 & 0.5 & 0.5 & 0.4 & 0.5 & 0.5 & 0.4 & 0.3 & 0.5 & 0.4 & 0.4 & 0.5 & 0.3 & 0.5 & 0.5 \\
\hline
\end{tabular}




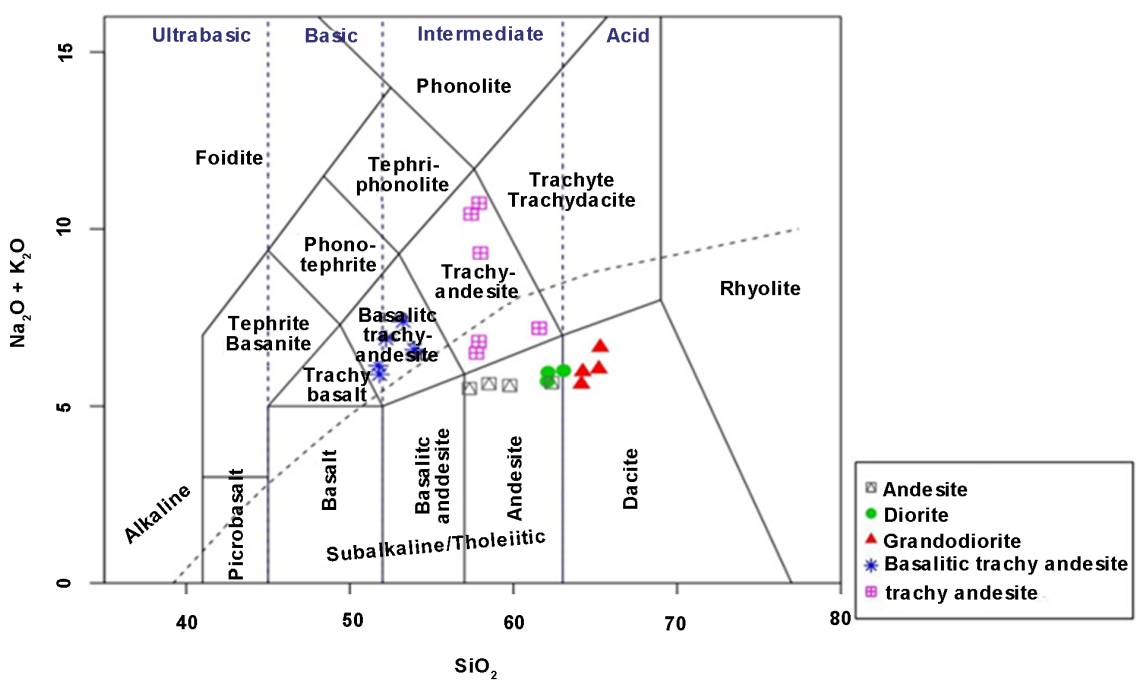

Figure 9. Total alkalis $\left(\mathrm{Na}_{2} \mathrm{O}+\mathrm{K}_{2} \mathrm{O}\right)$ versus $\mathrm{SiO}_{2}$ diagram for igneous rocks of Malek Siah Kuh area.

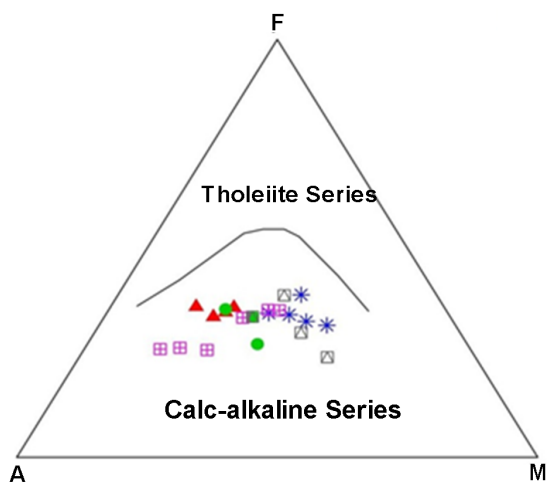

(a)

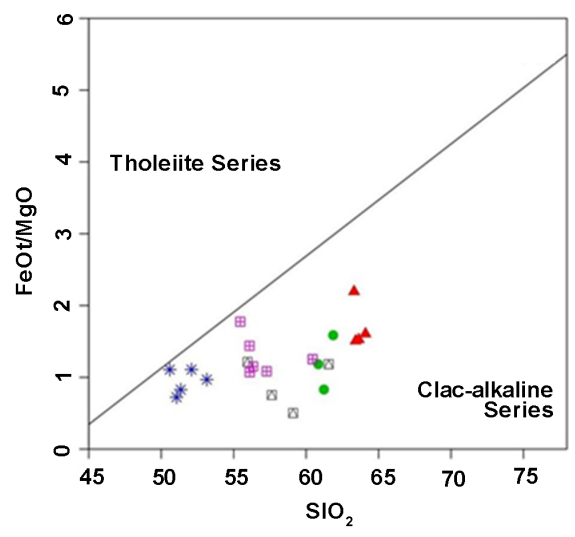

(b)

Figure 10. (a) AFM-diagram of plutonic and associated volcanic rocks of the study area; (b) $\mathrm{FeO}_{\mathrm{t}} / \mathrm{MgO}$ vs. $\mathrm{SiO}_{2}$ of igneous rocks in the Malek Siah Kuh area.

$\mathrm{K}_{2} \mathrm{O}$ (Figure 11) showed that most of the samples are calc-alkaline in nature. Thus, due to chemical and petrological relationships, these rocks are considered part of the calc-alkaline province which extends from Lut block into Sistan area. Therefore, the geochemical characteristic of igneous complex in Malek Siah Kuh was related strong subduction components. In the complex, $\mathrm{TiO}_{2}$ increases with decreasing $\mathrm{SiO}_{2}$, that consistent with magma evolution during differentiation from a mafic magma [30]. Despite the clear link between the compositions of plutonic complex that can be related to metaluminous or peraluminous but some volcanic rocks in the Malek Siah Kuh area are shoshonitic. They are enriched in LREE and depleted in $\mathrm{Ti}, \mathrm{Nb}$ and $\mathrm{Ba}$.

Plot of major elements versus silica (Figure 12) indicates that the rocks of the complex show smooth variations with gradual decreases in $\mathrm{CaO}, \mathrm{FeO}_{\text {(total) }}$, and $\mathrm{TiO}_{2}$ with increasing silica. The positive correlation of $\mathrm{Na}_{2} \mathrm{O}$ and incompatible elements $\left(\mathrm{Ni}, \mathrm{Zr}\right.$ and $\mathrm{La}$ ) with $\mathrm{SiO}_{2}$ (Figure 12 and Figure 13) and the negative 


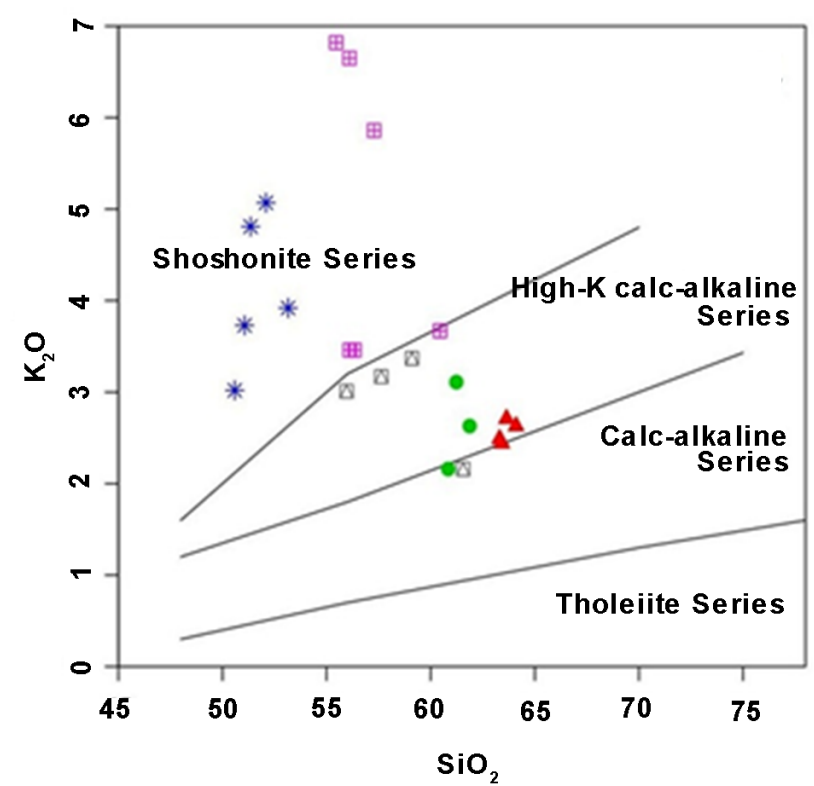

(a)

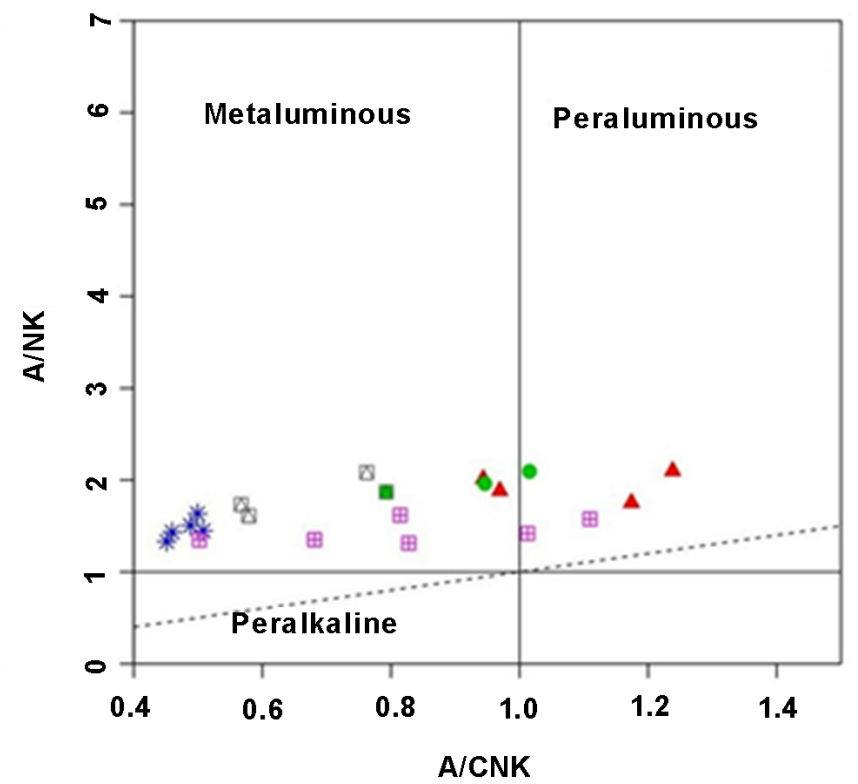

(b)

Figure 11. Plots of $\mathrm{K}_{2} \mathrm{O}$ vs. $\mathrm{SiO}_{2}$ (a) and A/NK vs. A/CNK (b).
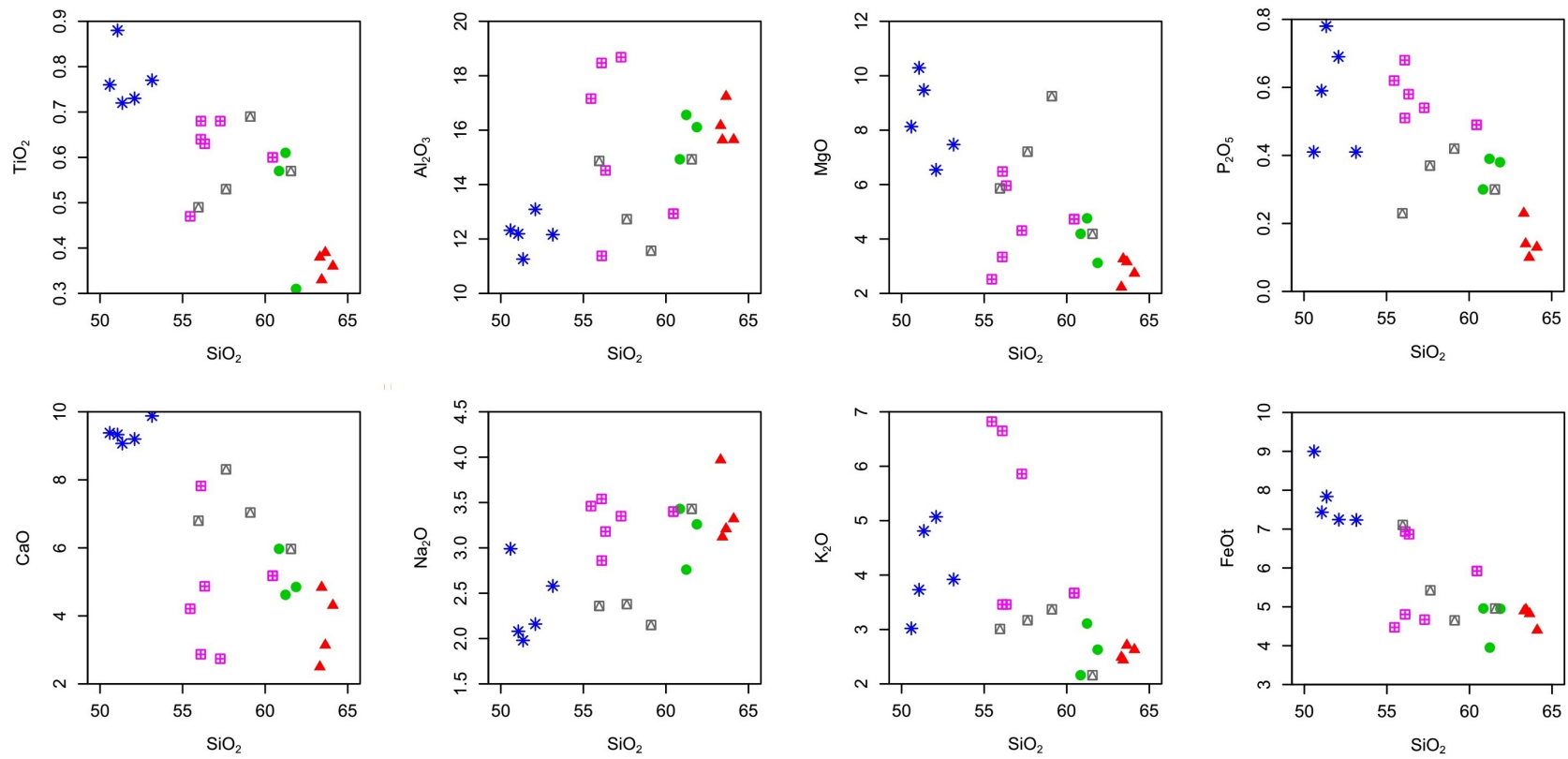

Figure 12. Selected Harker diagrams showing the major element variations of igneous rocks in the Malek Siah Kuh area.

correlations of $\mathrm{TiO}_{2}, \mathrm{MgO}, \mathrm{CaO}, \mathrm{FeO}_{\text {(total) }}$ and $\mathrm{P}_{2} \mathrm{O}_{5}$ with $\mathrm{SiO}_{2}$ (Figure 12 and Figure 13) show the impact of differentiation of magma in the magmatic evolution of igneous complex in the Malek Siah Kuh area. Beside these plots, the result of XRF and ICP-MS in Harker diagrams showed the effect of differentiation process as well as contamination phenomenon.

Diorite rocks of the complex are characterized by high $\mathrm{SiO}_{2}$ and $\mathrm{Al}_{2} \mathrm{O}_{3}$ contents but intermediate alkali and $\mathrm{MgO}$ contents. Geochemically, diorite-andesite unit is predominantly calc-alkaline and metaluminous in characteristics. These 

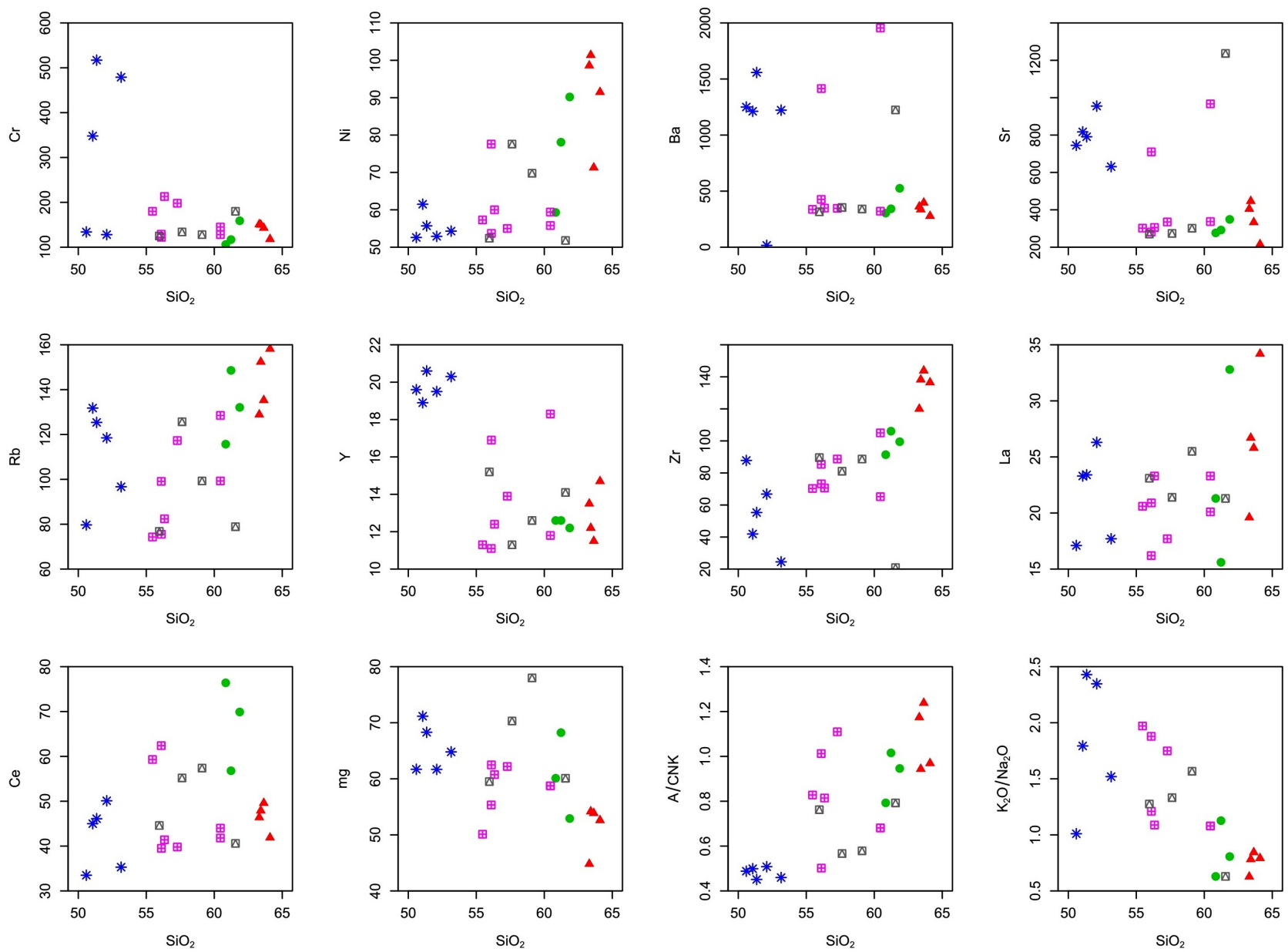

Figure 13. Selected Harker diagrams showing the trace element variations of igneous rocks in the Malek Siah Kuh area.

compositional characteristics suggest the parental magma of andesitic composition and this kind of high-aluminum magma is typically produced in subduction related settings particularly at continental margins [31]. Although the igneous complex in Malek Siah Kuh, crystallised from basaltic magma, however, granodiorites and trachyandesites are peraluminous and may have formed by assimilation of felsic continental crust.

Although, field relations of intermediate plutonic and acidic rocks do not indicate a direct petrogenetic link, but lithogeochemistry investigations showed some similarities in trace and rare earth element abundances. These evidences may indicate derivation from similar silicate melt source during differentiation from a mafic magma [30] and assimilation of crustal rocks. Immobile, incompatible elements (such as $\mathrm{Ti}$ and $\mathrm{Zr}$ ) exhibit highly significant positive correlation coefficients $(r)$ in cogenetic lavas, even when altered or metamorphosed [32]. In another case, the plot in the magnesian granitoid field indicates hydrous, oxidizing condition of the magma. The origin of magnesian granitoids has been interpreted as related to subduction processes [33].

Petrological studies and geochemical data (including REE and trace element analyses) has highlighted the fact that magma mixing was not responsible for the 
formation of intermediate rocks. In contrast, the trace element analyses and enrichment of LILE of the igneous complex relative to HFSE is suggesting calc-alkaline magmatism and involvement of strong subduction components.

The igneous complex shows a wide range of $\mathrm{Zr}$ (70.3 to $143.9 \mathrm{ppm}$ ), Y (11.1 to $14.7 \mathrm{ppm}$ ), $\mathrm{Sr}$ (276.6 to $1237 \mathrm{ppm}$ ), $\mathrm{Rb}$ (74.3 to $158.2 \mathrm{ppm}$ ) and $\mathrm{Nb}$ (10.2 to 14.5 $\mathrm{ppm}$ ) values. Moreover, these rocks contain high concentrations of the HFS elements, thus reflecting an enriched source. The enrichments in Th and LREE relative to HFSE and HREE in the primitive gabbros are characteristic of subduction related magmas [19]. The most obvious consequence of the geochemical study of REE elements is enrichment of LREE in compare of MREE and HREE (Figure 14). These evidences indicated the relative importance of differentiation process in rock forming minerals (e.g. plagioclase and hornblende). Therefore, based on the petrological evidences, the igneous complex was most likely derived from partial melting of subducted Sistan seafloor followed by fractional crystallization and wall rock assimilation of continental crust.

The intrusive rocks and associated volcanic suits of Malek Siah Kuh related to $\mathrm{Cu}-\mathrm{Fe}-\mathrm{Au}$ mineralization in the Sistan area are characterized by high $\mathrm{SiO}_{2}(\geq 59.8$ wt.\%), $\mathrm{Al}_{2} \mathrm{O}_{3}$ ( $\geq 15.5$ wt.\%), sodium $\left(\mathrm{Na}_{2} \mathrm{O} \geq 3.2\right.$ wt.\%), low $\mathrm{Yb}(\leq 2 \mathrm{ppm}), \mathrm{Y}(\leq 12$ $\mathrm{ppm})$, high La/Yb ratio ( $\geq 11.5$ ) and Low HFSE ( $\mathrm{Nb}, \mathrm{Ta})$ (Table 2$)$. Broadly, the characteristics of these rocks are geochemically similar to adakite. In addition to the petrological aspects, the chemical trend of major and trace elements from intermediate plutonic to acidic rocks showed arc related active continental margins (Figure 15 and Figure 16). The rocks in the study area are complex and in order to take account of this complexity, the diagram of Sr/Y versus $\mathrm{Y}$ (Figure 17) was used to distinguish adakite type rocks from normal arc igneous rocks. This is a practical illustration that plots of $\mathrm{MgO}$ wt.\% vs. $\mathrm{SiO}_{2}, \mathrm{Sr}$ vs. $(\mathrm{CaO}+$ $\mathrm{Na}_{2} \mathrm{O}$ ) and $\mathrm{Sr} / \mathrm{Y}$ vs. $\mathrm{Y}$ show the chemical differences between low silica adakite and high silica adakite types (Figure 18). Thus, plotting $\mathrm{La} / \mathrm{Sm}$ ratio vs $\mathrm{Sm} / \mathrm{Yb}$ ratio diagram (Figure 19) would allow for deducing the possible mantle source in the study area.

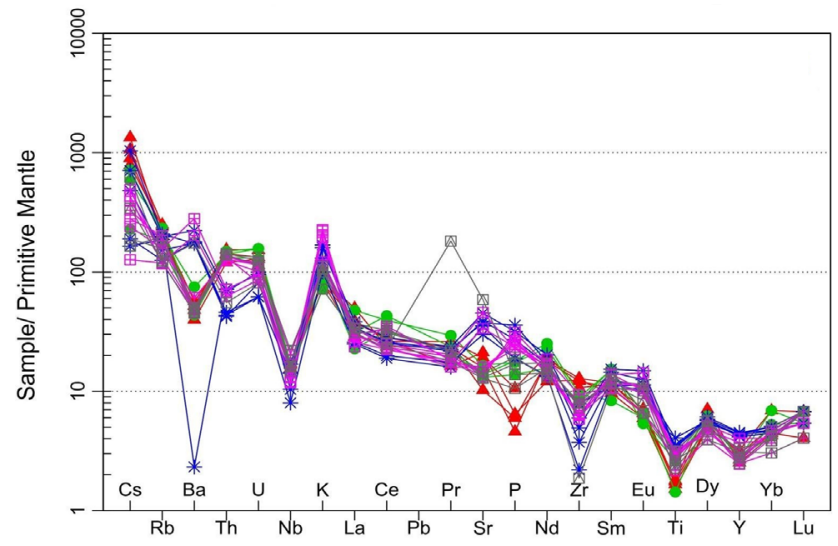

(a)

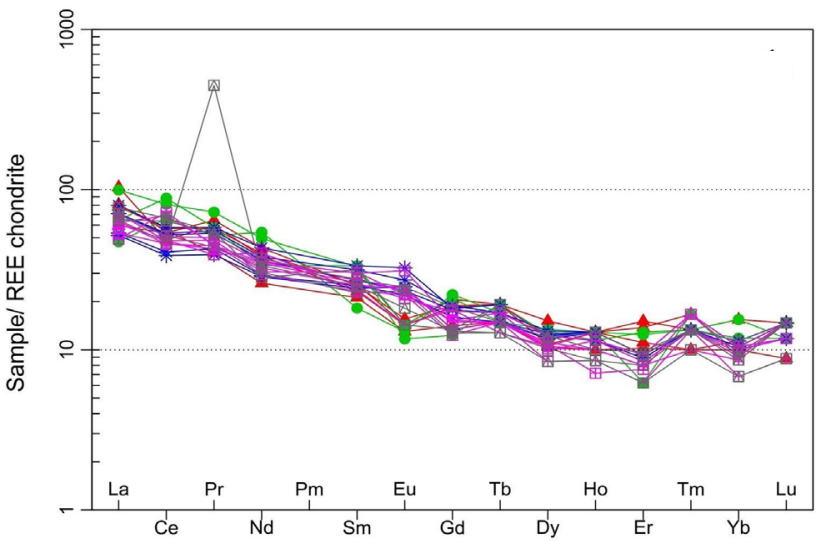

(b)

Figure 14. (a) Spider trace element; (b) REE elements normalized to MORB in igneous rocks in the Malek Siah Kuh area. 


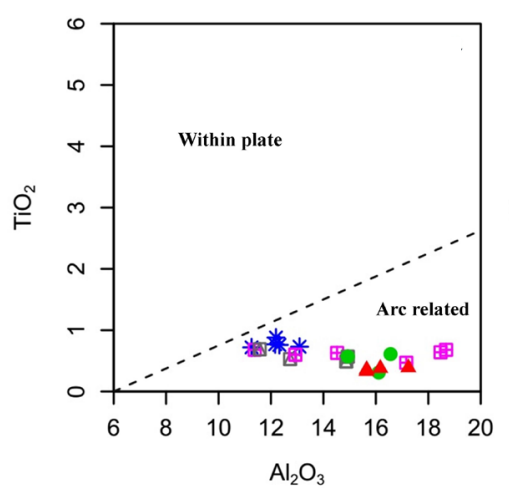

(a)

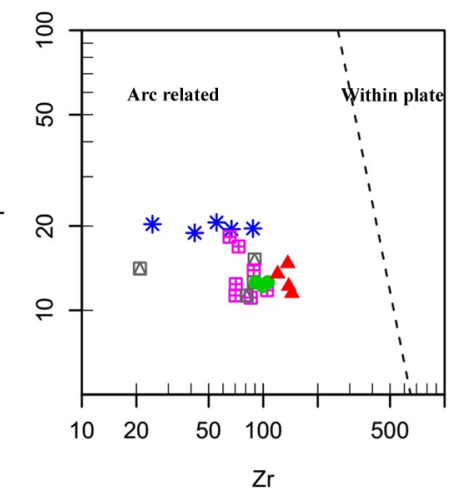

(b)

Figure 15. (a) Plots of $\mathrm{TiO}_{2}$ vs. $\mathrm{Al}_{2} \mathrm{O}_{3}$ and (b). $\mathrm{Y}$ vs. $\mathrm{Zr}$.

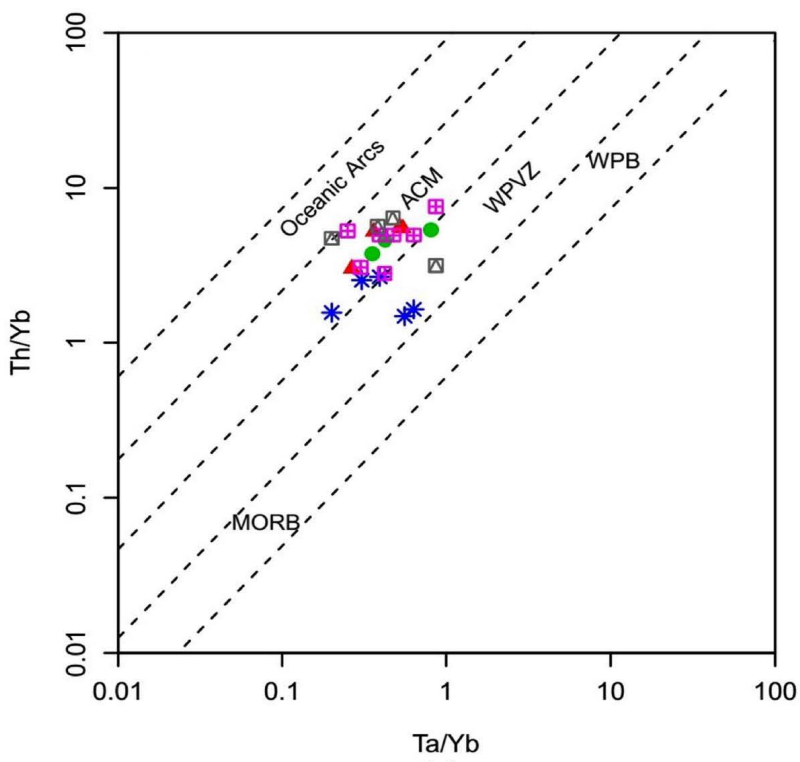

(a)

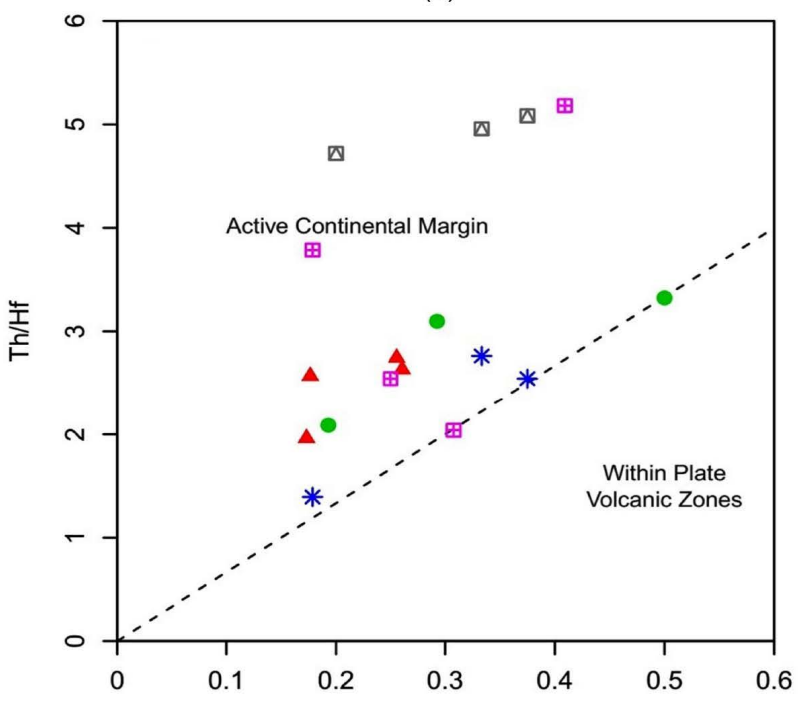

(c)

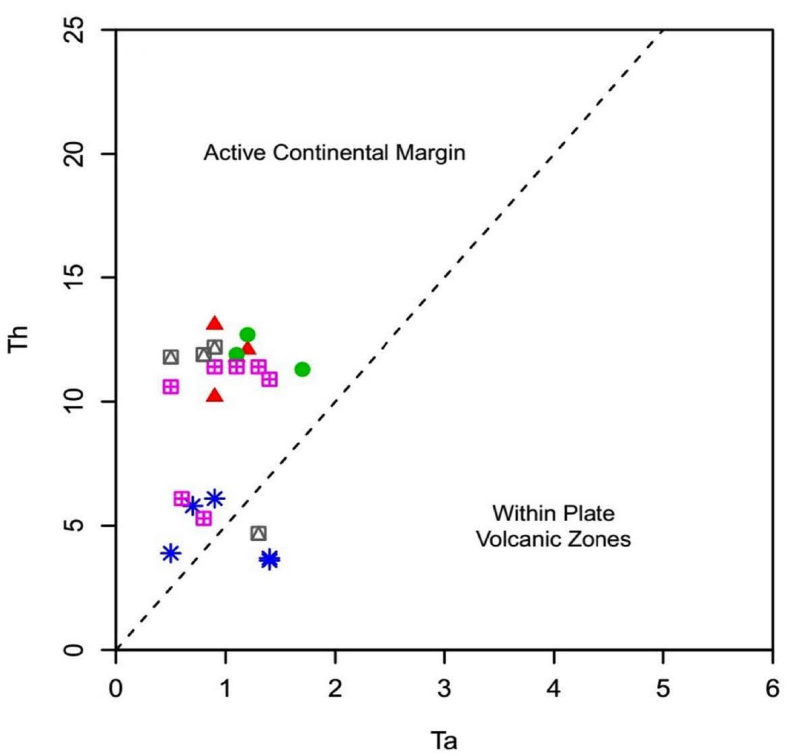

(b)

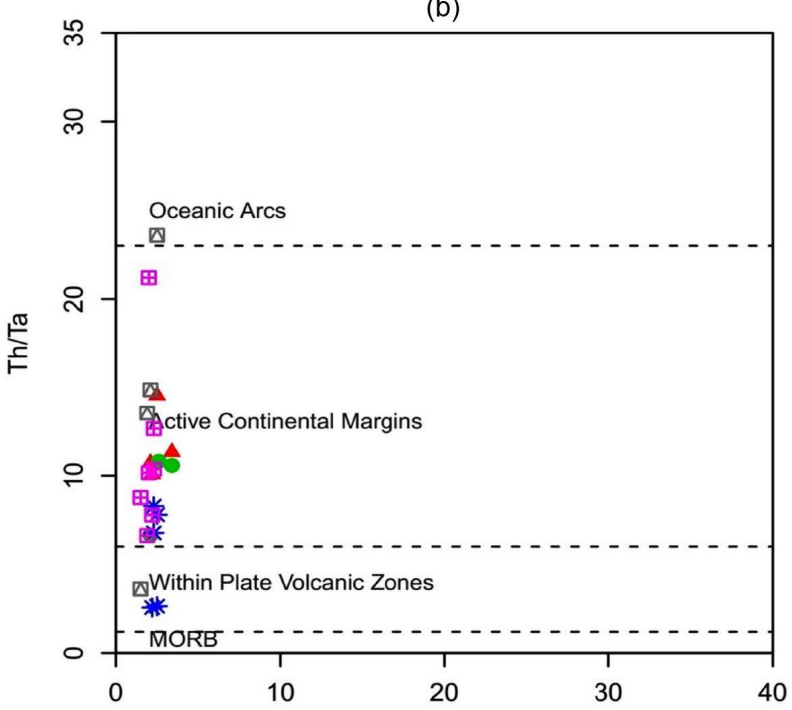

(d)

Figure 16. (a) Th/Yb versus $\mathrm{Ta} / \mathrm{Yb}$; (b) Th versus Ta; (c) Th/Hf versus Ta/Hf and (d) Th/Ta versus $\mathrm{Yb}$ diagram for igneous rocks of Malek Siah Kuh area. 


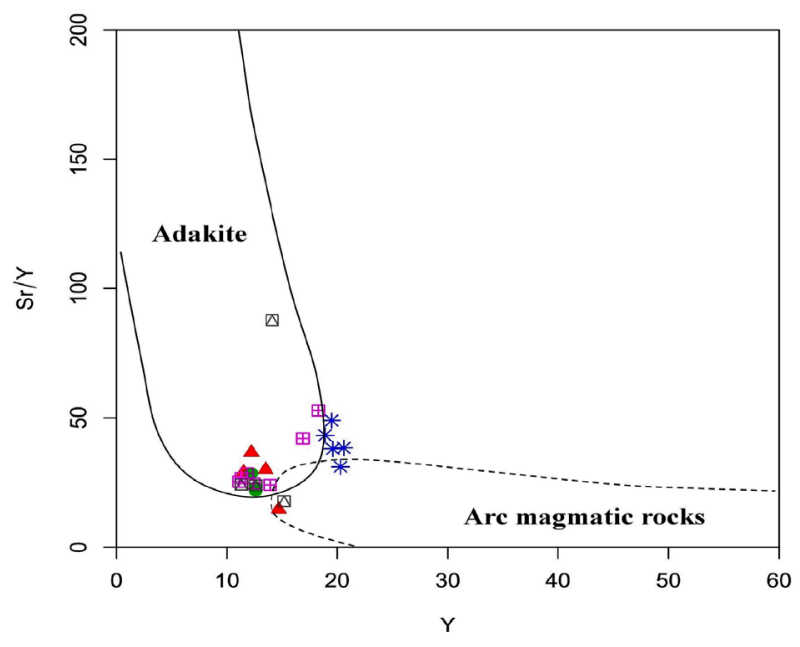

Figure 17. Plot of Sr/Y vs. Y. The diagram typically used to distinguish adakite from normal arc igneous rocks [4].

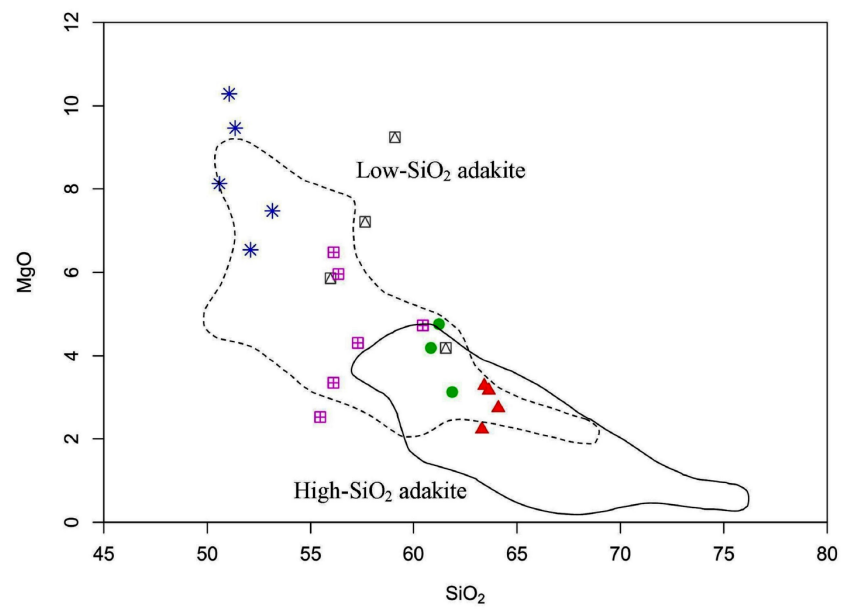

(a)

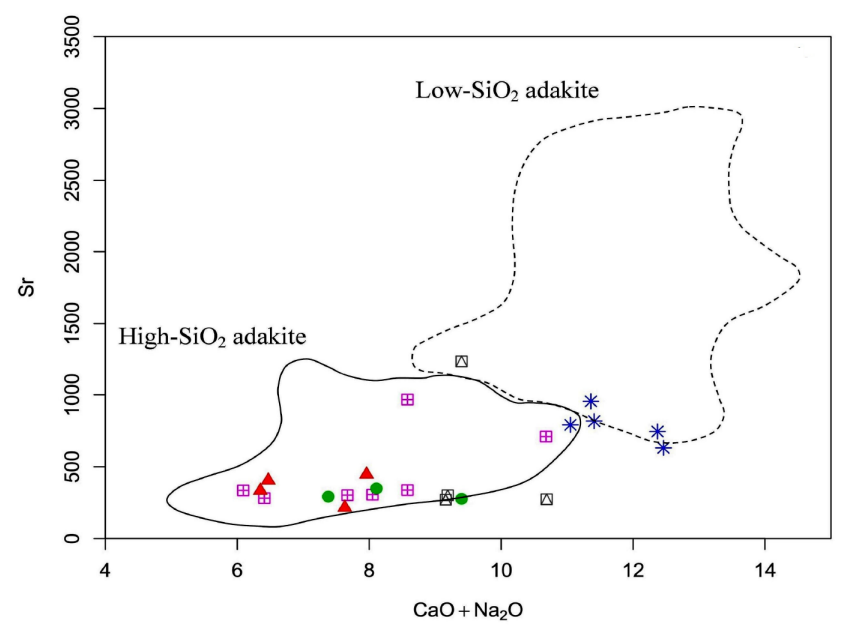

(b)

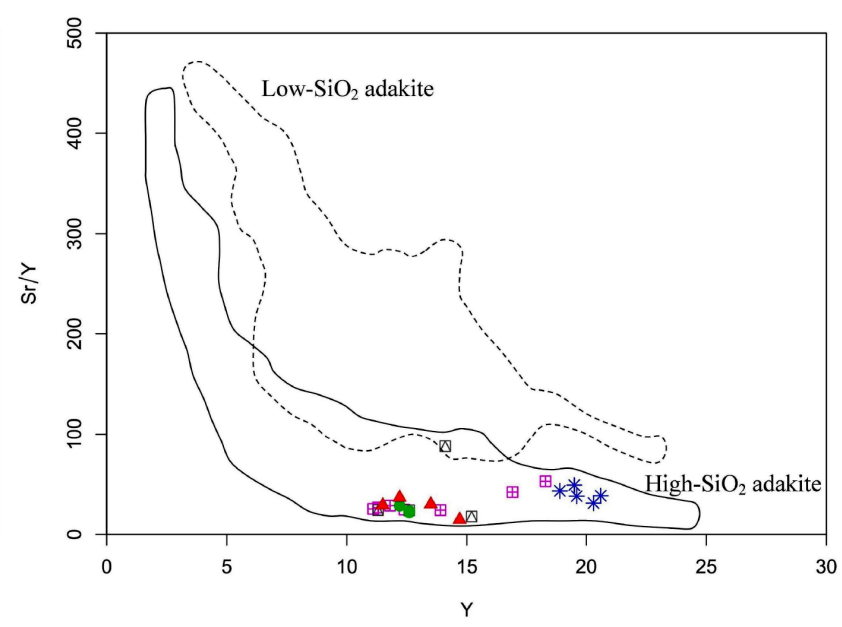

(c)

Figure 18. (a) Plots of $\mathrm{MgO}$ wt.\% vs. $\mathrm{SiO}_{2}$ wt.\%, (b) $\mathrm{Sr}$ vs. $\left(\mathrm{CaO}+\mathrm{Na}_{2} \mathrm{O}\right)$ wt.\% and (c) $\mathrm{Sr} / \mathrm{Y}$ vs.Y showing some of the chemical differences between low silica adakite (dotted field) and high silica adakite (solid field) varieties [15], for the Malek Siah Kuh adakitic rocks. 


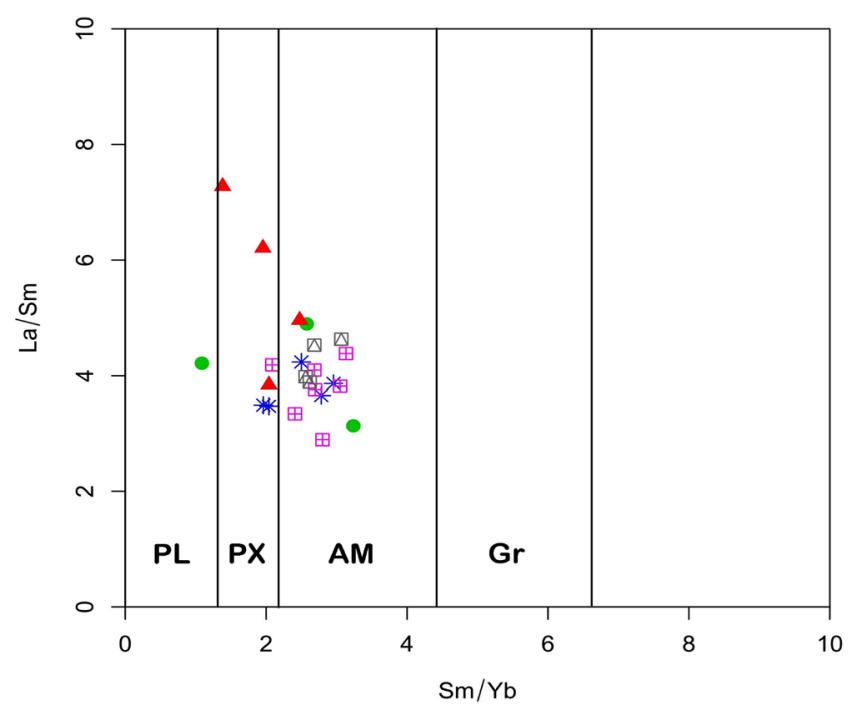

Figure 19. $\mathrm{La} / \mathrm{Sm}$ vs $\mathrm{Sm} / \mathrm{Yb}$ diagram to determine the possible mantle sources of the studied rocks. Most of the samples are in the range of amphibolite derived rocks [34].

Table 2. Comparison of the geochemical features of the studied rocks with geochemical features of adakite [35].

\begin{tabular}{cc}
\hline Adakite cognition criteria & Malek Siah Kuh adakitic rocks \\
\hline $\mathrm{SiO}_{2} \geq 56 \mathrm{wt} . \%$ & $\mathrm{SiO}_{2}: 59.8$ \\
$\mathrm{Al}_{2} \mathrm{O}_{3} \geq 15 \mathrm{wt} \%$ & $\mathrm{Al}_{2} \mathrm{O}_{3}: 15.5$ \\
$\mathrm{MgO}<3$ wt.\% & $\mathrm{MgO}: 4$ \\
$\mathrm{High} \mathrm{Na}_{2} \mathrm{O} \geq 3 \mathrm{wt} . \%$ & $\mathrm{Na}_{2} \mathrm{O} \geq 3.2 \mathrm{wt} . \%$ \\
$\mathrm{Sr}>300 \mathrm{ppm}$ & $\mathrm{Sr}: 800$ \\
Lack of negative anomaly Eu & Lack of negative anomaly Eu \\
$\mathrm{Y}<10$ & $\mathrm{Y}: 12$ \\
$\mathrm{Sr} / \mathrm{Y}>20$ & $\mathrm{Sr} / \mathrm{Y}: 66$ \\
$\mathrm{Yb}<1$ & $\mathrm{Yb}: 2$ \\
$\mathrm{La} / \mathrm{Yb}>20$ & $\mathrm{La} / \mathrm{Yb}: 11.5$ \\
Low $\mathrm{HFSE}$ 's $(\mathrm{Nb}, \mathrm{Ta})$ & Low HFSE's $(\mathrm{Nb}: 11, \mathrm{Ta}: 1.1)$ \\
\hline
\end{tabular}

It is clear that the presence of igneous activities (in the form of diorite-granodioritic complex), hosting the mineralization indicate a role of magma in the generation of ore forming magmatic hydrothermal systems. Adakites in subduction zones are now recognized to be particularly favorable for $\mathrm{Cu}-\mathrm{Au}$ mineralization [8]. Porphyry $\mathrm{Cu}-\mathrm{Au}$ deposits are generally derived from sulfur-rich, highly oxidized magmatic systems, with oxygen fugacities $\left(\mathrm{fO}_{2}\right)$ between the nickel-nickel oxide (NNO) and magnetite-hematite oxygen buffers [12]. [12] suggested that only slab-derived adakitic magmas or supercritical fluids would have a high oxidation potential to generate epithermal and porphyry $\mathrm{Cu}$-Au deposits.

$\mathrm{Cu}$ and $\mathrm{Au}$ mineralization in Malek Siah Kuh is mainly associated with diorite-granodiorite complex and by hydrothermal activities. In the study area, wall 


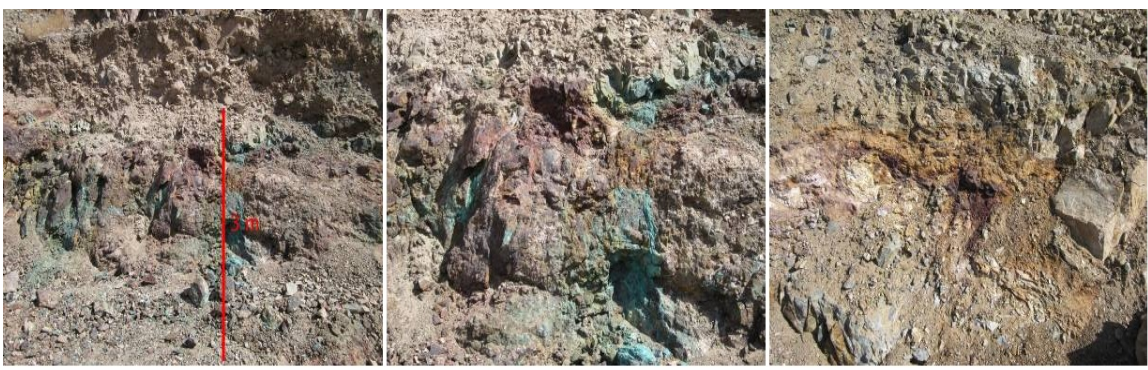

Figure 20. Photographs of typical alterations from $\mathrm{Cu}-\mathrm{Au}$ mineralization in the Malek Siah Kuh area.

rocks are commonly altered and polymetallic hydrothermal veins are common in the rocks of the complex (Figure 20). Based on set of petrological and geochemical-mineral deposit relations, three distinct stages of mineralization process can be recognized in the Malek Siah Kuh area. 1) The first stage is related to differentiation of primary magma followed by metal enrichment as well as subsolidus leaching by hot fluids. 2) The second phase appeared by ascending of the gas-rich magma (reduction in gas pressure) and the release of sulfur and arsenic. Mineralization is associated mainly with hydrothermal alteration. 3) The final stage was completed by hydrothermal activities leading to the generation of sulfidation (formation of gold and copper sulfides) and associated polymetallic $(\mathrm{Cu}, \mathrm{Au}, \mathrm{Fe})$ mineralization. Polymetallic mineralization formed quartz or chalcopyrite and veins associated with a number of polymetallic $(\mathrm{Cu}, \mathrm{Fe})$ sulfides.

\section{Conclusions}

The granitoid of Malek Siah Kuh is metaluminous to per aluminous and the complex is high calc-alkaline to shoshonitic nature. Petrology and geochemical data of mineralized granitoid intrusions of the study area showed a geochemical relationship with adakitic rocks with high $\mathrm{Al}_{2} \mathrm{O}_{3}$ (15.5\% wt.\%), $\mathrm{MgO}$ (4 wt.\%), $\mathrm{Sr}$ (800 ppm) contents as well as high $\mathrm{Sr} / \mathrm{Y}$ ratios, light rare earth element (LREE) enriched but low in $\mathrm{Y}(12 \mathrm{ppm}), \mathrm{Yb}(2 \mathrm{ppm})$ contents and heavy REE (HREE) depletion.

Based on set of petrological and geochemical-mineral deposit relations, three distinct stages of mineralization process can be recognized in the study area. The first stage is related to differentiation of primary magma, metal enrichment and subsolidus leaching by hot fluids. The second phase appeared by ascending of the gas-rich magma (reduction in pressure) and the release of $S$ and As. The final stage was accompanied by hydrothermal activities leading to the generation of sulfidation (formation of $\mathrm{Au}$ and $\mathrm{Cu}$ sulfide) and associated polymetallic $(\mathrm{Cu}$, $\mathrm{Au}, \mathrm{Fe})$ mineralization.

\section{References}

[1] Roberts, M.P. and Clemens, J.D. (1993) Origin of High-Potassium, Calc-Alkaline, 
I-Type Granitoids. Geology, 21, 825-828. https://doi.org/10.1130/0091-7613(1993)021<0825:OOHPTA >2.3.CO;2

[2] Thompson, A.B. and Connolly, J.A.D. (1995) Melting of the Continental-Crust: Some Thermal and Petrological Constraints on Anatexis in Continental Collision Zones and Other Tectonic Settings. Journal of Geophysical Research, 100, 15565-15579. https://doi.org/10.1029/95JB00191

[3] Altherr, R. and Siebel, W. (2002) I-Type Plutonism in a Continental Back-Arc Setting: Miocene Granitoids and Monzonites from the Central Aegean Sea, Greece. Contributions to Mineralogy and Petrology, 143, 397-415. https://doi.org/10.1007/s00410-002-0352-y

[4] Defant, M.J. and Drummond, M.S. (1990) Derivation of Some Modern Arc Magmas by Melting of Young Subducted Lithosphere. Nature, 347, 662-665.

https://doi.org/10.1038/347662a0

[5] Thiéblemont, D., Stein, G. and Lescuyer, J.L. (1997) Epithermal and Porphyry Deposits: The Adakite Connection. Comptes Rendus de P Académie des Sciences, Paris, 325, 103-109.

[6] Sajona, F.G. and Maury, R.C. (1998) Association of Adakites with Gold and Copper Mineralization in the Philippines. Comptes Rendus de PAcadémie des Sciences, Paris, 326, 27-34. https://doi.org/10.1016/S1251-8050(97)83200-4

[7] Martin, H. (1999) Adakitic Magmas: Modern Analogues of Archaean Granitoids. Lithos, 46, 411-429. https://doi.org/10.1016/S0024-4937(98)00076-0

[8] Defant, M.J. and Kepezhinskas, P. (2001) Evidence Suggests Slab Melting in Arc Magmas. EOS, Transactions of the American Geophysical Union, 82, 62-70. https://doi.org/10.1029/01EO00038

[9] Oyarzún, R., Márquez, A., Lillo, J., López, I. and Rivera, S. (2001) Giant vs Small Porphyry Copper Deposits of Cenozoic Age in Northern Chile: Adakitic vs Normal Calc-Alkaline Magmatism. Mineralium Deposita, 36, 794-798. https://doi.org/10.1007/s001260100205

[10] Smithies, R.H. (2000) The Archean Tonalite-Trondhjemite-Granodiorite (TTG) Series Is Not an Analogue of Cenozoic Adakite. Earth and Planetary Science Letters, 182, 115-125. https://doi.org/10.1016/S0012-821X(00)00236-3

[11] Kamber, B.S., Ewart, A., Collerson, K.D., Bruce, M.C. and McDonald, G.D. (2002) Fluid-Mobile Trace Element Constraints on the Role of Slab Melting and Implications for Arhean Crustal Growth Models. Contributions to Mineralogy and Petrology, 144, 38-56. https://doi.org/10.1007/s00410-002-0374-5

[12] Mungall, J.E. (2002) Roasting the Mantle: Slab Melting and the Genesis of Major Au and Au-Rich Cu Deposits. Geology, 30, 915-918. https://doi.org/10.1130/0091-7613(2002)030<0915:RTMSMA >2.0.CO;2

[13] Condie, K.C. (2005) TTGs and Adakites: Are They Both Slab Melts? Lithos, 80, 33-44. https://doi.org/10.1016/j.lithos.2003.11.001

[14] Rollinson, H. and Martin, H. (2005) Geodynamic Controls on Adakite, TTG and Sanukitoid Genesis: Implications for Models of Crust Formation, Introduction to the Special Issue. Lithos, 79, 270 p.

[15] Martin, H., Smithies, R.H., Rapp, R., Moyen, J.F. and Champion, D. (2005) An Overview of Adakite, Tonalite-Rondhjemite-Granodiorite (TTG), and Sanukitoid: Relationships and Some Implications for Crustal Evolution. Lithos, 79, 1-24. https://doi.org/10.1016/j.lithos.2004.04.048

[16] Petford, N. and Atherton, M. (1996) Na-Rich Partial Melts from Newly Under- 
plated Basaltic Crust: The Cordillera Blanca Batholith, Peru. Journal of Petrology, 37, 1491-1521. https://doi.org/10.1093/petrology/37.6.1491

[17] Kay, S.M., Mpodozis, C., Ramos, V.A. and Munizaga, F. (1991) Magma Source Variations for Mid-Late Tertiary Magmatic Rocks Associated with a Shallowing Subduction Zone and a Thickening Crust in the Central Andes. Geological Society of America, Special Paper 265, 113-137. https://doi.org/10.1130/SPE265-p113

[18] Wang, Q., Xu, J.-F., Jian, P., Bao, Z.W., Zhao, Z.H., Li, C.-F., Xiong, X.L. and Ma, J.L. (2006) Petrogenesis of Adakitic Porphyries in an Extensional Tectonic Setting, Dexing, South China: Implications for the Genesis of Porphyry Copper Mineralization. Journal of Petrology, 47, 119-144. https://doi.org/10.1093/petrology/egi070

[19] Bea, F. (1996) Behavior of Trace Elements during Magma Genesis and Evolution. Geology, Vol. II. https://pdfs.semanticscholar.org/a999/0c8782f2c5ede387dd448fe6779f308786e0.pdf

[20] Tirrul, R., Bell, I.R., Griffis, R.J. and Camp, V.E. (1983) The Sistan Suture Zone of Eastern Iran. Geological Society of America Bulletin, 94, 134-150. https://doi.org/10.1130/0016-7606(1983)94<134:TSSZOE >2.0.CO;2

[21] Camp, V.E. and Griffis, R.J. (1982) Character, Genesis and Tecto. nic Setting of Igneous Rocks in the Sistan Suture Zone, Eastern Iran. Lithos, 3, 221-329. https://doi.org/10.1016/0024-4937(82)90014-7

[22] Hubbard, T.N. (2003) Information, Decisions, and Productivity: On-Board Computers and Capacity Utilization in Trucking. American Economic Review, 93, 1328-1353. https://doi.org/10.1257/000282803769206322

[23] Rowan, L.C. and Mars, J.C. (2003) Lithologic Mapping in the Mountain Pass, California Area Using Advanced Spaceborne Thermal Emission and Reflection Radiometer (ASTER) Data. Remote Sensing of Environment, 84, 350-366. https://doi.org/10.1016/S0034-4257(02)00127-X

[24] Hewson, C.A., Jardine, A., Edwards, M.R., Laza-Stanca, V. and Johnston, S.L. (2005) Toll-Like Receptor 3 Is Induced by and Mediates Antiviral Activity against Rhinovirus Infection in Human Bronchial Epithelial Cells. Journal of Virology, 79, 12273-12279. https://doi.org/10.1128/JVI.79.19.12273-12279.2005

[25] Mars, J.C. and Rowan, L.C. (2006) Regional Mapping of Phyllic and Argillic-Altered Rocks in the Zagros Magmatic Arc, Iran, Using Advanced Space Borne Thermal Emission and Reflection Radiometer (ASTER) Data and Logical Operator Algorithms. Geosphere, 2, 161-186, 2 Plates.

[26] Coll, C., Caselles, V., Valor, E., Niclos, R., Sanchez, J.M., Galve, J.M. and Mira, M. (2007) Temperature and Emissivity Separation from ASTER Data for Low Spectral Contrast Surfaces. Remote Sensing of Environment, 110, 162-175.

https://doi.org/10.1016/j.rse.2007.02.008

[27] Di Tommaso, I. and Rubinstein, N. (2007) Hydrothermal Alteration Mapping Using ASTER Data in the Infiernillo Porphyry Deposit, Argentina. Ore Geology Reviews, 32, 275-290. https://doi.org/10.1016/j.oregeorev.2006.05.004

[28] Goetz, A.F.H., Vane, G., Solomon, J.E. and Rock, B.N. (1985) Imaging Spectrometry for Earth Remote Sensing. Science, 228, 1147-1153. https://doi.org/10.1126/science.228.4704.1147

[29] Le Bas, M.J., Le Maitre, R.W., Streckeisen, A. and Zanettin, B. (1986) A Chemical Classification of Volcanic Rocks Based on the Total Alkali-Silica Diagram. Journal of Petrology, 27, 745-750. https://doi.org/10.1093/petrology/27.3.745

[30] Barnes, S.-J. and Lightfoot, P.C. (2004) Formation of Magmatic Nickel-Sulfide Ore Deposits and Processes Affecting Their Copper and Platinum-Group Element Con- 
tents. Economic Geology One Hundredth Anniversary Volume, 179-213.

[31] Wilson, M. (1989) Igneous Petrogenesis: A Global Tectonic. Oxford University Press, Oxford, 466 p. https://doi.org/10.1007/978-1-4020-6788-4

[32] Cann, J.R. (1970) New Model for the Structure of the Ocean Crust. Nature, 226, 928-930. https://doi.org/10.1038/226928a0

[33] Frost, B.R., Arculus, R.J., Barnes, C.G., Collins, W.J., Ellis, D.J. and Frost, C.D. (2001) A Geochemical Classification of Granitic Rocks. Journal of Petrology, 42, 2033-2048. https://doi.org/10.1093/petrology/42.11.2033

[34] Haschke, M.R. and Ben-Avraham, Z. (2005) Adakites from Collision-Modified Lithosphere. Geophysical Research Letters, 32, 14-32. https://doi.org/10.1029/2005GL023468

[35] Castillo, P.R. (2012) Adakite Petrogenesis. Lithos, 134, 304-316. https://doi.org/10.1016/j.lithos.2011.09.013 